\title{
Part 2 \\ Mapping the Landscapes: Identifying historical and contemporary signposts and benchmarks
}

Cecille DePass and Faye Lumsden

Colonial legacies are embedded like massive conglomerates in and on the land. Brown's essay, like a virtual field trip, focuses on her childhood memories of growing up in rural Jamaica. Yvonne Brown demonstrates the historical shifts between a colonial centre in the former colonized periphery. (A concept once elaborated by Ann Norton who taught us). Sandra Dixon's poem, complements Brown's essay, by imagining the life of an enslaved person. Moving to the present, DePass' essay highlights some important experiences of participating in the Jamaica Geographical Society (JGS) and the Geography Department's Conference held in summer 2016, to celebrate the Department's Golden Anniversary. Extracts from one of the first UWI Geography publications, submitted by Faye Lumsden, illustrate the key issues in teaching and learning Geography, in the 1960s and 1970s. Finally, Part 2 concludes with Colin Hewitt's Photo Journal. Hewitt's vivid, visual field trip, documents some of the cultural history underpinning the campus' Geography. It offers a transition to Part 3, in which our Geography field trips moved off campus.

“...words... have a texture, they have a soul as well as a meaning”. (Mary di Michele, as quoted by Elaine Kalman Naves, 1998). ${ }^{1}$

"Stories must have a home in a community of listeners for whom the story makes a claim that will be remembered". (Parin Dossa, 2004, Politics and Poetics of Migration, as quoted in Book Project Collective, 2015).

Part 2, explores some of the taken for granted assumptions, issues and implications associated with living, learning, working and teaching in the Caribbean region. A region in which colonial legacies are embedded, like massive conglomerates, in and on the land.

Yvonne Brown, draws on childhood experiences of rural Jamaica (near Carron Hall), in order to present, a few of the memories which continue to haunt her. Brown's essay, is essentially, a virtual field trip and a case study in historical geography in which she traces some of the key linkages between memory and the land. In this essay, Brown describes the people of the village of Hazard, and the lands which surrounded an abandoned sugar plantation and cattle pen. In Brown's childhood, the people in the village were extremely poor. Brown's essay demonstrates that the relationships between centres and peripheries shift and change. ${ }^{2}$

Sandra Dixon adopts a poetic voice to imagine experiences of being enslaved. In this sense, her poem speaks to some of the key issues in Philip Sherlock and Hazel Bennett's (1998) work.

Cecille DePass focuses on a few roles and functions, usually associated with oral and narrative histories and stories. To do so, she concentrates on examples from the 2016 Geography $50^{\text {th }}$

Cultural and Pedagogical Inquiry, Winter 2019, 11(1), pp. 21-60

ISSN 1916-3460 @ 2019 University of Alberta

http://ejournals.library.ualberta.ca/index.php/cpi/index 
Anniversary, UWI Conference. (See Anne Hickling-Hudson's Photo Journal in this volume, for conference highlights). She concludes by commending the founders, professors and instructors for their continuing efforts to create collegial communities. (See too, for example, essays by: Angela Cunningham-Heron, Jeremy Collymore, Blossom (Stokes) O'Meally-Nelson, Adrienne Chung Aarons, Fitzgerald M. Jeffrey, Ros Dopwell, and Mike Morrissey in this volume).

DePass reminds the readers of the exemplary record for teaching, research and service which the founders established and which were developed more fully by future leaders in the Department.

As importantly, Part 2 includes a few extracts from one of the first publications, written and produced by the Geography Department's students, faculty and administrators. The extracts identify some of the perennial problems inherited from a colonial school curriculum. ${ }^{3}$

Part 2 concludes with a series of photographs. Colin Hewitt's Photo Journal illustrates graphically, important aspects of UWI's historical and contemporary landscapes. When we attended UWI, in the late 1960s, there were no visible, historical markers and signposts. Accordingly, the campus' rich history, was unknown to most of us, as we crossed the campus, several times each day. Hewitt's contribution, further, acts as reminders of the history underlying the physical geography of the Mona Campus. When textual and visual images are taken together, the contributions by Hewitt, Brown, Dixon, DePass (i.e., the description of the campus' physical setting in the introduction), complemented with Faye Lumsden's, Google Earth map of the campus, all depict the enduring and unique relationships between humans and the land, as a coherent theme.

In general, Part 2, like much of the book, indicates a willingness to take stock, to revisit and reflect on major triumphs and challenges associated with individual and institutional formal/nonformal lived educational experiences. The book's narratives contribute to personal, organizational and disciplinary stories of continuity and change. Furthermore, the narratives highlight courage, hope, resiliency, the beauty of the land and planet earth. 


\section{Endnotes}

1. Quote by Mary di Michele, extracted from DePass' Qualitative Research Methodology course, Oral and Narrative History, Faculty of Education, U Calgary. Mary di Michele is a well known Italian Canadian academic in Literature (See websites online, e.g. Interview by Joseph Pivato, Professor, Centre for Language and literature, Athabasca University, and Aurora Issue, 2008).

2. Ann Norton, herself, from a former British colony, in central Africa, introduced us in the late 1960 s, to the centre-periphery theory which was then, dominant in some of the Social Sciences. Almost 10 years later, a noted Norwegian academic in peace and conflict studies, Johan Galtung (1976), elaborated on the key concepts and introduced subtle, yet telling, conceptual distinctions. Galtung created a dynamic, interactive world systems model which explained the structural relationships between the economically developed north (centre) and the economically underdeveloped, less developed, developing south (periphery). DePass' doctoral research (1988), drew on Norton's and Galtung's conceptual thinking.

3. One remembers that in the Department's early days, Ms. Beverley Phillips prepared all articles and publications. The documents were reproduced on gestetner machines. As students, we were invited, from time to time, to collate several publications.

\section{References}

DePass, C. (1988). From Periphery to Periphery: Employment Equity for Visible Minorities in Canada. Unpublished doctoral dissertation. Calgary: University of Calgary.

Dossa, P. (2004). Politics and Poetics of Migration. Toronto: Canadian Scholar's Press. In Book Project Collective. (2015). Resilience and Triumph: Immigrant Women Tell Their Stories. (With Rashmi Luther, Vanaja Dhruvarajan et al.), Toronto: Second Story Press.

Galtung, J. (1976). A Structural Theory of Imperialism. In Barclay, W., Krishna Kumar and Ruth P. Simms. Racial Conflict, Discrimination and Power. Historical and Contemporary Studies. New York: AMS Press Inc., pp. 391-418.

Sherlock, P. and Bennett, H. (1998). The Story of the Jamaican People. Kingston: Ian Randle Publishers and Princeton: Marcus Wiener Publishers. 


\section{Linking Memory, History, Narrative with Jamaican Landscapes}

\section{Yvonne Brown}

In this essay, I discuss ways in which I have braided my life-long observations of uses and abuses of Caribbean black bodies, with narratives concerning how such bodies carry haunting, painful memories of legacies of the Middle Passage, as well as, an inherited colonial history of sugar, molasses, rum and enslavement.

In the popular imagination, writing which draws heavily on autobiographical memory is variously termed memoir, autobiography, life writing, life history or creative non-fiction. Such research is dependent on two major issues. Firstly, the writer's purpose, and secondly, the context within which the writing seeks validation. In the academy, where research warrants valid truth claims, theorists include such personal writing under the rubric of narrative inquiry and auto-ethnography.

These types of qualitative research, are usually thought to be quite controversial. Methodological research concerns include the following: whether the research meets the positivist tests, borrowed from the Natural and Social Sciences of validity, reliability, generalization and replication. Narrative inquiry, in contrast, is framed in different ways. It attempts to make sense of personal experiences and involves emotional content. Accordingly, the texts produced are more akin to literature and narrative than to scientific research. Thick, rich descriptions; voice; authenticity; trustworthiness and the quality of the writing to prompt readers into identifying and mapping some of their own stories are accepted criteria for conducting, writing and assessing merits and values of narrative inquiries (Conle, 2000; Ellis and Bochner, 2000; Zinsser, 1995).

An essential aspect of the method is the dialogue and tension which develop between the observed or experienced, and the imagined. On one hand this type of narrative is 'non-fiction', in that it describes actual, firsthand accounts of events and incidents in one's life. To be later, supported, complemented, enhanced or refuted by primary and secondary sources of data. On the other hand, the narrative is 'fiction'. In my research, I applied creative writing techniques to imagine a version of my life, and thereby, construct a particular kind of truth. ${ }^{1}$

In looking back at the experience of using my memory as the main source of data for the constructions of my stories, I realized that Olney's (1998) work resonated with my research process. He explains in detail that memory recalls origins; returns us by way of recollection, imagination and invention to the human beginning, at which point one can see unfolding, as by an inner necessity, the course of the life of an individual, of a nation, of humankind (p. 97). Through memory, we look forward, look at, and look back. Olney states that memory has three aspects: memory itself when it remembers things; imagination when it alters or imitates them; and invention when it gives them a new turn or, puts them into proper arrangements and relationships (p. 104).

As importantly, he reminds us that memory always involves the deepest kind of emotional engagement. Olney convincingly argues: "Emotions are essential to the creation of a memory Cultural and Pedagogical Inquiry, Winter 2019, 11(1), pp. 21-60 ISSN 1916-3460 @ 2m019 University of Alberta http://ejournals.library.ualberta.ca/index.php/cpi/index 
because they organize it, establish its relative importance in a sequence of events much as a sense of time. ... [further] order is essential for a memory to be considered a memory, and not as a thought or, vision at some particular instant, unrelated to past events" (p. 373).

There were times when the pleasure of family secrets uncovered, or childhood observations relived gave me breath-taking joy. At other times, the remorse, grief, sorrow and rage that I felt towards brutalities and injustices against black people overwhelmed me and made me question why I was writing these stories at all. Could I not just forget them? No! I could not forget because I am not allowed to forget - the memory is in my blood.

In my veins runs the blood of the enslaved and the enslaver. The contemporary global nightmarish scenes of brutality against and among black people demand that I hear the screams from the silences of the past. They must be heard, to wake us from our dozing complacency, to move towards the need for healing and restorative justice for the dislocation and dispossession of African peoples, past and present.

In describing the significant events of my life in Jamaica within the historical geography of a post-slavery and colonized society, I was, and still am, informed by Toni Morrison's literary exposition of the part memory played in the interior life of the character Sethe, in her novel Beloved. Morrison undertook, among other things, the task of imagining the psychology of mothering during slavery. Taking into account the historical processes of a past set in a time of fugitive slave laws and their execution in Ohio, Morrison articulates the complexities of embodied personal, painful, memories in her characters around four constructs: (i) remember as recollection; (ii) re-member as in replacing the severed body parts as often occurred during enslavement; (iii) memory as in the human capacity of mind to store inestimable amounts of sensory data - simultaneously at the conscious and unconscious - waiting to be retrieved in the thought and creative processes of narrative; and (iv) re-memory, the process of remembering and it is the events remembered. The four constructs go well beyond merely, passing on a memory. Instead, we use memory, as a place/site to dwell in/on: to excavate the repressed, the forgotten, the ignored, the erased. Finally, the act of re-membering, tends to superimpose the past upon the present (Moberly, 1993, p. 358, in Gates and Appiah, 1993).

In my own research, I have imbued memory with four further overlapping dimensions: autobiographical, genetic, topographical, and archival (Brown, 2005, pp. 213-220). In this essay, I concentrate on one dimension, specifically, the links between memory and landscape and merely, mention another dimension, the importance of archival research.

In tapping into my memories of turning points in my life, I came to appreciate how much memory was stored in landscapes. Landscapes record not only the millennia of earth's evolution, and give a region its physical geography, but as Geographers know well, the topography can be read and interpreted for evidence of past and present, human activities and interventions on the land and its flora and fauna. In Jamaica, we know the history, taught from the 1960s in high schools.

A careful look at some maps of Jamaica shows place names indicating the Spanish, English, and African presence, but little or nothing, of the Taino or Arawak presence. So too, the ruins of great houses, sugar mills, water wheels and abandoned wharves along the coastline conjure up

Cultural and Pedagogical Inquiry, Winter 2019, 11(1), pp. 21-60

ISSN 1916-3460 @ 2019 University of Alberta

http://ejournals.library.ualberta.ca/index.php/cpi/index 
images and questions of sugar's past (See Colin Hewitt's Photo Journal in this part of the book). The British Empire - as indeed all empires - has left in its wake enduring physical reminders of past power and dominion of the land and, has inevitably, marked the people. Formidable architecture reinforced imperial administration, evident in government buildings, various styles of churches denoting different Christian denominations, special cemeteries, monuments to colonial victories, and statues to conquerors, all exist throughout, different parts of the island and Caribbean. The sea routes, donkey trails, roadways, and railway tracks tell much about plantation industry, local commerce and international trade. All these landmarks are reminders of successive eras of conquests, colonization, and the sustenance of the British and other western European empires in the Caribbean.

Another important dimension of memory, the archival, provides proof and evidence to help construct personal and historical narratives. Archival memory is comprised of the powerful and symbolic records such as diaries, literature, travelogues, legal documents, government records, institutional practices, plantation and ship's ledgers, and institutional records, such as those pertaining to banking, and insurance. Though not always regarded as such, colonial archives constitute significant, memory banks.

But not all archives are of documentary forms. The retention of folk wisdom of African ways of being and philosophies for survival are encoded in the dynamic Patois/Creole or Africanized English. The Patois/Creole is spoken with an African musicality sprinkled with percussive accents of Scottish, Irish, and Cockney lilts, indicating regional variations in settlement patterns. The Patois is used extensively in dialogues and in sophisticated theoretical explanations unrecognized as such. The Creole and Nation languages spoken throughout the Caribbean are rich sources of valuable memories, providing data to complement and verify autobiographical memories.

\section{The People of Hazard}

The memory of the people of Hazard has haunted me all my life. I have returned so many times in my imagination and my nightmares to scenes of abject poverty etched in my mind. Who were those people? Where did they come from? In my readings of Jamaican history I have tried to find answers to explain their living conditions. The following is an extract from my dissertation:

I had a chance to re-visit Hazard under different circumstances. Eutedra's brother owned a cane piece there, and I went with her to visit him. Her brother lived at the foot of a mountain, from which cascaded a waterfall. As the volumes of water rolled off the mountaintop, they sprayed big clouds of mist, which came to settle into a big, beautiful, blue lagoon. Water ran off the lagoon into an awesome deep blue hole, from which people dipped up their drinking water with calabashes. The blue shimmering lagoon pulled me forward like a magnet. The place was spooky. My head began to spin. I must have been about to fall in because someone pulled me roughly by the scruff of my neck asked "You wan fe drown pickney?"

The people of Hazard: I infer that the monetary worth of these people was no longer calculable in the plantation ledgers of old, alongside the steers, mules, ploughs, and wheelbarrows. Speculating that Carron Hall and Hazard must have been plantations, I referred to the survey of plantations in Jamaica during the eighteenth and nineteenth centuries by Barry Higman (1988).

Cultural and Pedagogical Inquiry, Winter 2019, 11(1), pp. 21-60

ISSN 1916-3460 @ 2 m019 University of Alberta

http://ejournals.library.ualberta.ca/index.php/cpi/index 
Maps and blueprints suggested evidence of cattle pens and pasture, with many sugarcane pieces around, and the waterfall offering a source of energy for a waterwheel, and a supply of fresh water for people and cattle.

Around, small farmers cultivated ground provisions in yams, potatoes, and taro and other vegetables. The African workforce lived in kraals called Negro houses, located on the edge of the plantation. Confirmation that Hazard was indeed a plantation was found in the 1941-42 West Indies Year Book including also the Bermudas, The Bahamas, British Guiana, and British Honduras. There I found that Alfred and William Champagne owned the Hazard Estate, which was listed each year until 1946-47, when it was no longer listed as such.

In a conversation with Evadne Sherrief, a schoolmate of my brother and sister in Carron Hall, I confirmed that the Champagne brothers still owned the cattle pasture at the time I had been at school in the area. According to Higman, it was common for pastures to continue after estate owners ceased to produce sugar. The cattle were then raised for beef and milk.

The dismantling of the sugarcane crop of the plantation explains, at least in part, the poverty. Who were these people?

\section{Epilogue}

I looked to find out more about Carron Hall and in particular, the role of the Presbyterian mission after 'emancipation', when the plantations and estates were abandoned. I am trying to understand the whole area with respect to the cane pieces and the sugar estates to which they supplied cane.

The sugar-cane pieces and cattle stand out. John Stewart, writing in 1823, advised prospective planters that the four great desiderata in setting up a sugar plantation are: (1) goodness of soil; (2) easiness of access; (3) convenience of distance to the shipping place; and (4) a stream of water running through the premises. He advised that if there was not a naturally occurring stream running through the property, one should be created from a nearby source, to send down a supply. If water cannot be obtained easily, a well or a pond should be sunk to draw or collect it.

This passage helps me to sketch out more clearly my memory of a reservoir in Carron Hall as well as the Hazard Falls and the lagoon below. I wonder if that deep blue hole into which the water of the lagoon ran, was man-made, or if it resulted from the natural erosion of the limestone of the area. Certainly there were many concealed sinkholes into which cattle sometimes fell.

What do the details of the ruins of the landscape of Hazard and Carron Hall invite me to remember? The works by Higman on plantation and slave economy in Jamaica, as well as, his extensive study on the Mount Pellier Plantation in Jamaica, are particularly instructive in trying to piece together the childhood memories imprinted on my mind, by the landscape when I attended Carron Hall Infant School.

Several things come to mind. For one, the number of cane pieces that were being worked and through which I passed to school is indicative of small cane farmers who had to grow their cane to sell to the Grays Inn Factory to earn their livelihood. After emancipation and the wholesale desertion of unprofitable sugar estates, small farmers took up the job of raising the sugarcane to

Cultural and Pedagogical Inquiry, Winter 2019, 11(1), pp. 21-60

ISSN 1916-3460 @ 2019 University of Alberta

http://ejournals.library.ualberta.ca/index.php/cpi/index 
sell to the factories that continued to process the sugarcane into unrefined sugar, molasses, and rum.

Second, judging from the number of cattle that I remember roaming close to the area, after the abandonment of the large sugar estates, the motive power of cattle was no longer needed. Some estate owners abandoned the planting of sugarcane and either sold the land or let it lie fallow. Other owners converted cattle pens from raising draught-animals to raising dairy and beef cattle, for local consumption by those who could afford to buy the milk and beef. It was obvious that the people of Hazard could not afford to buy, so they seemed to have been in a state of malnutrition. Some of the cane pieces were converted into pasture of guinea and pangola grass to support a larger herd of cattle.

As Higman points out, in the heyday of sugar production cattle pens and sugar cane plantations had a symbiotic relationship. The cattle pens reared the steers and oxen for the motive power that ran the mills, and the drays and carts that transported the cane. When the plantation no longer needed the motive power of cattle, and cattle-rearing needing relatively less labour, the labourers were rendered redundant. The dairy where young boys were being trained, that I saw during my nature walks with the infant school, seems to have been established by the Presbyterian Church, to train some young black boys to work with cattle. In our correspondence, Mrs. Elliot (my infant school teacher), mentions that milk cans were collected to take to the Bybrook Condensery for the manufacture of sweetened condensed milk. Like a curse, poor mothers fed this sweetened condensed milk to their children, not knowing that they were undernourishing their children.

Another memory of slavery and emancipation evident in the landscape of Carron Hall was the growing of a large variety of ground provisions: yams, sweet potatoes, cocoas, dasheens, coconuts, plantains, and bananas. It seems that these provision grounds were the only sphere of control for slaves, and which continued to flourish after emancipation as a way of providing sustenance and income. Those ex-slaves who could acquire land became peasant farmers. The Presbyterian Church capitalized on this abundance and hard work though the services conducted at harvest time. As a little child attending the Carron Hall Infant School, I can remember going to the harvest services in the middle of the day. We little children had to huddle and sit quietly. We watched while, the minister and his choir walked triumphantly into the church, up the aisle, and approached the church altar which was beautifully decorated with the best: local vegetables, ground provisions, and fruit. Each year, the altar would be filled with a display of only the choicest and best food produced by the farmers and their families.

In this story, I have pieced together vivid memories of an episode of schooling from my early childhood, which occurred around 1949. In so doing I revisited, in my imagination, the topography of sugarcane plantations derived from my narrative of a marginalized black community in one Jamaican locale. With these data so mined, I consulted primary and historical sources to explain the history of the people's role in sugar plantations and their fate in postemancipation Jamaica. In so doing, I have woven a tale about Caribbean bodies, history, landscape and narrative into a readable, informative and entertaining auto-ethnography. 


\section{Endnote}

1. Parts of this essay are extracted from my lengthier article posted on the website, of the Harriet Tubman Institute, York University, Ontario, entitled: Caribbean Bodies, Memories, History, Narrative and Auto-ethnography. The article explicates the significance of memory in my continuing research. After some five decades of embodied pain and ruminations, I was moved to inquire formally, into black peoples' human conditions; beginning with my own autobiographical memories of growing up in Jamaica from 1943 to1965. After at least, ten years of detailed self and cultural studies, and the intense consumption of black peoples' cultural productions: literature, history, art, cinema, memoirs, and philosophy, I produced a doctoral dissertation at The University of British Columbia, entitled Bodies, Memories and Empire: Life Stories about Growing up in Jamaica 1943-1965 (2005), and later, a memoir, Dead Woman Pickney (2010) published by Wilfrid Laurier Press.

\section{Selected Bibliography}

Brown, Y. (2005). Bodies, memories, and empire: Life stories about growing up in Jamaica 1943-1965. EdD Dissertation, Vancouver BC: The University of British Columbia.

Bryan, P. (2000). The Jamaican People 1880-1902: Race, Class and Social Control. Kingston, Jamaica: The University of the West Indies Press.

Conle, C. (2000). Thesis as narrative or "What is the inquiry in narrative inquiry?" Curriculum Inquiry, 30(2), pp. 180-210.

Ellis, E. and Bochner, A. P. (2000). Autoethnography, personal narrative, reflexivity: Researcher as subject. In Denzin, N. K. and Y. S. Lincoln eds. Handbook of_Qualitative Research. Thousand Oakes: Sage Publishers.

Higman, B. W. (1995). Slave Population and Economy in Jamaica 1807-1834. Kingston, Jamaica: The University of the West Indies Press.

Mobley, M. (1993). A different remembering: Memory, history, and meaning in Beloved. In Gates, H. \& Appiah K. (Eds.). Toni Morrison: Critical perspectives past and present. (pp. 356-365). New York: Amistad.

Olney, J. (1998). Memory and narrative: The weave of life-writing. Chicago: University of Chicago Press.

Walvin, J. (2001). Black Ivory: Slavery in the British Empire. Oxford: Blackwell.

Zinsser, W. (1995). Inventing the truth: The art and craft of memoir. New York: Houghton Mifflin Company.

Email: yshorterbrown@gmail.com

Cultural and Pedagogical Inquiry, Winter 2019, 11(1), pp. 21-60

ISSN 1916-3460 @ 2019 University of Alberta

http://ejournals.library.ualberta.ca/index.php/cpi/index 


\section{THE SLAVERY STORY}

\section{Sandra Dixon}

They were here from the beginning

That's what they told me

All the pain they bore

Mingled with self-hate

Induced with anguish

Their eyes revealed their sorrows

Past shadows lurked there

Possessing their enslaved minds

And consuming their fragmented psyche

Beaten and abused

Hopeless and rejected

They carried the burdens of our forefathers

Entrenched somewhere deep inside

Confined to a life of indelible hardships

I envisioned the shackles on their feet

Their ankles swollen and bruised

The hot sun scorching their bodies

Deepening the black pigmentation of their skin

Their human existence seen as a curse rather than a blessing

They were paralyzed because of their race

And stifled because of their ancestry

Some ran in search of freedom

Others stood and fought

Trying to resist racial discrimination

They were imprisoned in a social system

In which they were society's victims

They sought empowerment from God

Holding on to their faith for solace and strength

Many rose above the debris of defeat

And conquered the fears that imprisoned their minds

Others became entangled in a web of anger and destitution

Consumed by racial infestation

Living in a world of injustice

They craved for a revolution

To abolish slavery's destruction

Email: womanofinfluence1@yahoo.com

Cultural and Pedagogical Inquiry, Winter 2019, 11(1), pp. 21-60

ISSN 1916-3460 @ 2 m019 University of Alberta

http://ejournals.library.ualberta.ca/index.php/cpi/index 


\section{Sharing our stories ourselves: Oral and Narrative histories}

\section{Cecille DePass}

Recording and documenting individual and community memories, via timeless traditions of oral and narrative histories, offer some people including, the often unsung heroes among us, an opportunity to share stories of memorable life experiences in educational institutions. In many cases, unfortunately, different types of institutional insiders, egs. present/former: students, graduates, instructors, faculty, administrators and support staff, remain largely invisible. Their voices are seldom heard. Their contributions seldom recognized. Although their productivity and unstinting services are vital to the organization's continuing effectiveness and longevity.

- By sharing our stories, in conversations (oral or written), we gain, strengthen and enhance our voices. Perhaps even more importantly, we gain a sense of agency. In doing so, we validate our work and lived experiences. At times, we lay foundations which may become institutional legacies. Our stories of the past, form celebratory and cautionary tales for the next generation of students to either emulate, or ignore or discard.

- By sharing our stories, we accomplish many tasks and functions associated with building real and imagined communities. Quite obviously, community building activities occur in multiple ways, times and places.

Sometimes, too, in informal conversations, at formal/informal social gatherings, as a result of sharing our lived experiences, cracks, fissures and faults may develop in organizational layers. As a result, discrete divisions between members of institutions in work units, departments, divisions, and faculties may change, if only for fleeting moments in time.

Two examples, among many worthy of note, occurred at the well attended social gatherings of the 2016 Geography Conference. The first, was organized and hosted by David Barker and his family, on the lawns of their beautiful floodlit garden, at their UWI home in order to mark, with a flourish, the end the first day of the Geography $50^{\text {th }}$ Anniversary Conference.

The second, was the grand gala, the Jamaica Geographical Society's (JGS) formal dinner meeting, at the hotel, on the Friday night, to conclude a successful conference. At this meeting, Geography's Barry Floyd, Vernon Mulchansingh, several professors, including Wilma Bailey and Eleanor Jones, and former senior administrator, Beverley Phillips, were acknowledged for their outstanding contributions to Geography.

The Department's founders, including Drs. Floyd and Mulchansingh, were commended for being 'pathbreakers' with respect to their teaching, research and service (personal communication with Vernon Mulchansingh, December 2016). In essence, at the second event, the founders and key individuals who have left a rich legacy for the Department were given public recognition.

At the same conference, there were two more excellent examples of sharing lived experiences which should be noted. Eleanor Jones' panel which grew into an interactive seminar sparked a 
particularly, lively discussion regarding major contributions of Geography to one's career and life.

The second, the closing seminar, explicated in graphic terms 'some war stories' of field trips/work in the 1990s (See videos produced. Beverley Phillips organized the taping of several key seminars, during the conference).

Central perennial issues and dilemmas which have challenged and continue to challenge the study and teaching of Geography and Social Studies, in the Caribbean, the USA and Canada, are highlighted in the following extracts from The Fledgling (Volume 1, No. 2, 1971-1972). One notes that Barry Floyd, as well as, Keith Rowley and Vincent George, using different perspectives, demonstrate ways in which research and lived experiences tend to question some of the taken for granted, conventional theories and wisdom generated by the northern academics.

It is a truism that grand explanatory narratives from the centre are often taught as being universal truths. Yet, they are often questioned, modified and sometimes, overturned and discarded by research and lived experiences of thinkers in/from the periphery, or individuals from the centre who live and work in the former peripheries. The extracts, from The Fledgling, indicate such challenges. 


\section{Faye Lumsden's Extracts from The Fledgling (Vol. 1, No. 2, 1971-1972)}

Several portions of an early copy of The Fledgling, identified and submitted by Faye Lumsden are included in order to illustrate the following:

- The academic and applied triumphs and challenges of teaching, learning and conducting research in Caribbean Geography in the early 1970s.

- The importance of field trips/work which were organized by the faculty and professionals in the field.

- Barry Floyd's farewell essay to the faculty, students and the JGS.

- Keith Rowley's critique of the structural and systemic limitations and constraints of teaching and learning Caribbean Geography, at that time. Rowley concludes by issuing a clarion call to the profession and publishers and by documenting recommendations for changes.

- By concentrating on the fallacies in teaching Caribbean climatology in high schools, Vincent George's essay summarizes current theories and lived experiences in order to erase inaccuracies in conventional knowledge and wisdom.

- Finally, Mary Virtue, an emerging geologist, presents case studies of three types of landslides in different parts of the country. 
(Vol. 1, No. 2, 1971-1972)
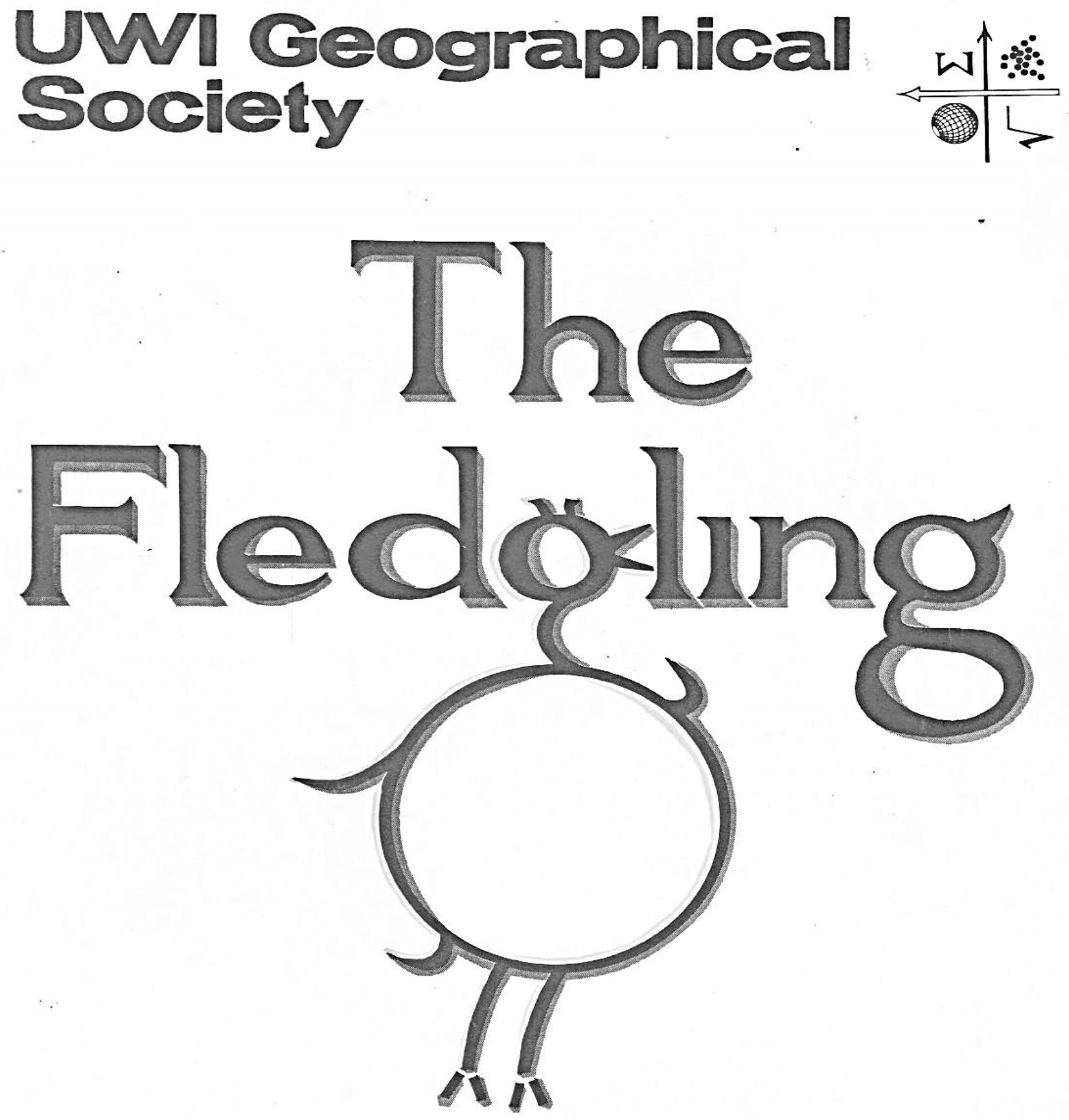


\section{PRESIDENT'S ADDRESS}

The Geographical Society of U.W.I., functions as an extra-curricular orgapisation whose chief concern lies in developing a greater interest in and enthusiasm for Geography which cannot be achieved in the milieu of the classroom. Consequent upon this the annual programmes of the society are designed mainly to "smooth out the jagged edges" of our classroom teaching. Of the various techniques employed the Field Trip has always been the most rewarding from the point of view of giving the student first hand experience in the line of observation, analysis and mapping of the landscape.

\section{FOREWORD}

In the last publication the editor rashly promised that there would be three issues for this academic year. He had added that the last of these would be an annual. Coleridge would be pleased by the editor's present mental state.

The reason for advancing the date of the annual and by so doing eliminating a second edition is that students claim that 'the beat is on' and in the final term they definitely would not have time for 'such things'. At least this was the response from a minute section who then went on to help. A slightly larger group wanted to help but 'couldn't get a topic'; some students said what they had to say then went back to their books - they said "What magazine?' The majority knew that they could make no contribution but 'Why not check out ... . ?' So that . . . out of a total of 132 students there is a problem of scarcity. There is, too, a serious lack of creativity and an apparent overemphasis on work.

Readers would have noticed that the name of the magazine has changed from 'Geographia Caribbeana' to 'The Fledgling'. While we are aware of the effort that went into the selection of the orig-
This year (1971-1972) our programme of activities has generally followed the pattern set in previous years. It has been for our society, a year of which we can be justly proud of our achievements. Our most ambitious plan-a weekend Seminar at Newcastle - was a resounding success. As part of this exercise we undertook a Field Trip to the Yallahs Valley Land Authority Project at Top Mountain which included among other things, interesting interviews with farmers, the value of which cannot be over-emphasised. There has also been a Caving Expedition to the Green Grotto Caves at Runnaway Bay. In addition, we had a series of talks and a film show.

Again this year, the society was

inal name, the present committee felt that the name connoted an image that was not substantiated by the magazine. There is an implication of professional geographers at work and some people went so far as to claim that the name sounded 'Latin American'. There is nothing wrong with a Latin American sound to a name except that with the emphasis on your own thing' and with the move away from jargon, we thought a simple more relevant name would be more to the point. 'The Fledgling' was chosen because it gave the impression, correct, of young apprentice geographers trying out their wings. The very subtle can trace the metaphor of wings through quills to the ignoble 'Youth' pen. The even more subtle can invoke the shades of Auden and Icarus.

In this issue the articles are concerned again at one level or another with things Caribbean. They would not be summarised here as the 'Contents' page does that. However, there is one point to be made. We have begun what one hopes is an interesting and would be a lasting precedent. There is included the text of a talk given to the Society by Mr. Johnson of U.T.C. This is to enable people who don't and can't come to meet- successful in the publication of our magazine "Geographia Caribbeana" but one achievement of which all our members can be proud is the publication of this edition of "Fledgling" which we hope will serve as the introduction to our year books in the future.

For the second time, our year will be climaxed by a week-long Work Camp with the North Clarendon Self-Help Scheme. Finally, the Society wishes to extend its sincere gratitude to all who helped in making this a most successful and enjoyable year.

\section{G. O. ODWIN, President.}

ings to have a better idea of what is meant when the Secretary reports: Mr. $\mathrm{X}$ from $\mathrm{Y}$ gave a lecture entitled Z. It is also included for the sake of the many who still insist that talks at Society meetings are mere extensions of classroom work.

With regard to cost one apologizes if the small amount gives the impression that the magazine is not worthwhile. More seriously, whatever profits are made they will NOT be put into the I.C.C.'s 'kitty' They will be used for two similar projects. First of all, together with what contributions the Geographical Society can raise elsewhere, part of the proceeds would be sent to aid the University of Bangladesh in its revitalising programme. In relative terms we are worse off than the widow, but if the gesture initiates similar gestures from other societies and clubs, it will be a good thing. The rest of the profits will help to finance the second annual trip to Morgan's Pass at the end of the academic year to live and work with the farmers.

Our thanks to those who helped. Special thanks to Dr. Floyd who unobstrusively g a ve encouragement; to R. Ealla and the advertisement team; to Diane for the

(Continued on Page 24) 
tradition, and after 1860 , led to the permanent appearance of revivalism in Jamaica, which has in recent years, I suspect become colonised by the influx of American pentecostalism.

The salvationist tradition is thus a rather complex one. From its inception it was divided into white and black varieties, and this bifurcation has continued down to our own day. Parallel to this tradition, but in recent years tending to separate out from it is what might be called the prophetic.

The prophetic tradition is that aspect of Christianity which leads to public comment and often action in society. We have seen how the great tradition in the salvationist pattern eschews public action, except when matters of personal morality are concerned. The little tradition is where we find the prophets.

The first of course is Sam Sharp. Sharp was a deacon in Burchell's Baptist Church in Montego Bay, and from all reports a perfectly orthodox Christian. At least in part because of his Christianity he could see no reason why he should remain a slave, if as he judged, the time was ripe to strike a blow for freedom before it was too late. Hence his organisation of the strike which misfired and became the revolt of 1831-1832. In this same tradition we may place George William Gordon, a one time Presbyterian who was in 1865 , leader of an independent congregation in Kingston, and Paul Bogle, who was deacon in a Native Baptist Church in Portand. These are men who, either because they wert Christians felt that they must act in society as a whole in the interest of Christian social righteousness, or who felt that way anyway, and saw that Christianity did not stand in their way, or positively led them in that direction.

After 1865, Jamaica in some ways went to sleep, and this was certainly the case after 1914. Garvey I suppose represents a kind of off beat example of this prophetic pattern, but it does not really revive until the appearance of the
Rastas. Although I said I was going to confine myself to Christianity, and if I understand the orthodox Rasta theology correctly, it cannot be described as Christian, it can be seen as a kind of Christian fall out, a non-Christian movement which cannot be explained apart from the thorough soaking which the Jamaican psyche has received from Christianity, especially in its salvationist, biblicist form.

The Rastas biblicism is plain enough. It is in the Bible that they find the prophecies believed to have been fulfilled in the accession of Haile Seliassie, or Ras Tafari. Their monotheism, their eschatology, and so forth are all clearly a reinterpretation of the Old Testament, and indeed, the fact that they are social critics can be seen as in line with the scathing social critique which is characteristic of men like Amos or Jeremiah.

The point I want to make about the Rastas is that they were the first people in Jamaica to develop a serious, coherent critique of the society which matured in the early years of this century, the out of many one people society.

At its best, say in an institution like the Presbyterian Church, out of many one people meant something. In the courts of the Presbyterian Church all men, whatever their appearance were equal. The church never had an effective 'Mission Council' or separate meeting of missionaries which really ran the church. But out of many one people also means equal rights for all who think white. That it called for equal rights, and in the Presbyterian $\mathrm{Church}$ at least meant it, is commendable. That it insisted that people think white, and then, very inconsistently, failed to provide the educational facilities whereby people could learn to think white is a signal failure, although in a poverty stricken place like Jamaica before World War II, they might have had some excuse. It was, to return to the point, the Rastas who pointed this out, clearly and dramatically, with a great deal more punch than Garvey had, and, as you can see by perusing Rex Nettleford's Mirror Mirror, what the Rastas put forward, then utter heresy if not nonsense, in the forties, is now the orthodox left, and taught in such eminently respectable institutions as the UWI and even, thank God UTCWI. It may even be, wonder of wonders, that the salvationist (Continued on Page $2 \vec{i}$ )

\section{FOREWORD}

(Continued from Page 1)

photography; to A. Jones who ploughed through the originals and especially to the people who were reckless enough to take time off.

V. GEORGE, Editor.

\section{FROM THE SECRETARY}

(Continued from Page 3)

The society extends a warm "Au revoir" to Dr. and Mrs. Floyd and the Floydlings - no pun intended. Dr. Foyld has shown sustained interest in our activities and was responsible, unobstrusively, for the trips to North Clarendon for example. We feel sure that the Floyds will get what they deservethe best. We say good-bye and "Press on" to Miss Norton who is leaving for Hawaii at the end of the academic year. We also wish to express our thanks to Mr. Frank who invariably arranged for us to get the use of the refrigerator; to Dr. Mulchansingh for the purchase of beers, the use of the maps and general advice; to Miss Norton for her help in securing Mr. Girvan and Mrs. Bailey for her willingness; to Dr. Eyre for pinning down the lecturer from the Met. Office. To the other people who talked with us Mr. Johnstone who dared to address a Geography class of sceptics and Mr. Payne who, as a soil scientist, took us down to earth, we wish to record our appreciation.

Finally to Beverley who typed the last issue and then trained a group of students to operate the duplicating machine, the societv tends its sincere regards. All in all it has been a good year so far and we expect it will continue thusly. 


\section{YA-SO .... A COMMENT FROM "THE MAN IN HEAD OFFICE."}

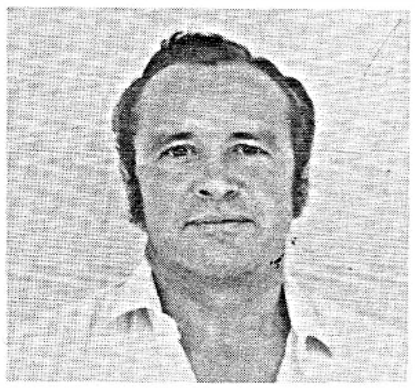

BARRY FLOYD

This latest issue of the student Geographical Society magazine, the third since its inception in 1969 , reflects a growing maturity of geographic thought that augurs well for the advancement of the subject here in the Caribbean. A critical questioning which is the hallmark of scientific enquiry is reflected in several of the contributions, whose authors may well be among the leaders of thought in West Indian geography over the decades ahead.

This is an age of dissatisfaction and discontent with éstablished procedures in many realms of life, not just the academic. In as far as the ideas expressed by our student writers challenge the traditional training and concepts, which admitted still form part of the undergraduate programme in geography at U.W.I. (as well as the overwhelming bulk of the geography curricula in West Indian schools), they can only be welcomed. They may well lead to revisions or changes of emphasis in the syllabuses, to accommodate the rising expectations of young, sociallyconscious scholars.

The extent to which indigenous Caribbean geographers can contribute to applied or "action" studies of real-world issues, with a view of effecting changes in the life-styles of individuals, West Indian society, and the "system" at large, has yet to be demonstrated. The special ability of West Indian students to perceive the spatial

Page Twenty-eight problems of, e.g., poverty-ridden peasant cultivators on derelict hillside farms, or poorly-paid unskilled labourers crowded into depressed urban dwellings, should be capitalized upon. At the same time it is, I am persuaded, essential for a rational objectivity and academic sense of perspective to be maintained, if the geographer s concern to achieve a scientific analysis and interpretation of spatial realities is to be honoured.

The geographical problems of the West Indies are by no means unique in the developing world, and it would be quite wrong to develop a peculiarly parochial approach to their solution. Many other Third World States (IIIW IIIW $_{3}$, IIIW $_{4} \ldots$ IIIWn) are facing comparable stresses and strains in society and are wrestling with similar physical and ecological handicaps in their economic development. The paths blazed since independence by African geographers in Ghana, Nigeria, Uganda, Kenya and Tanzania for example, and Indian and Malayasian scholars concerned with spatial and locational studies, are directly relevant to forthcoming efforts by Caribbean geographers to map their strategies for the consolidation and expansion of the discipline in this part of the world. One can only wish the next generation of West Indian scholars well in their geographic endeavours.

I take this opportunity to bid an official farewell, in print, to the flock of fledgling geographers at present in residence at U.W.I., as well as to those who have gone forth to test their wings in the realworld beyond Mona campus.

There are a number of reasons behind my resignation, after six years in Jamaica, from the headship in geography. Not least of these is the realization that one's effectiveness as an expatriate in the "head-office" seat has been reduced over the last year or so, and it is therefore time for a change (in academic life, as in politics). I have, too, professional interests in the larger problems of African geography to pick up and pursue, while my five children deserve an opportunity to further their education and choose careers in their father's homeland, having been nomads in several continents throughout their lives so far.

We are going to the University of Durham which has, incidentally the largest and best-equipped department of geography in the U.K., where there should be many opportunities for maintaining links with Caribbean geographers and renewing ties with African colleagues. I am hoping particularly that some of you may be persuaded to venture to North-east England for post-graduate studies after completion of your U.W.I. degrees. I shall be passing the message back to student society officials in due course, regarding this and other prospects for further studies in Caribbean and Third World geography in the U.K.

Meanwhile, every success in the June examinations, and in the fruition of your own career plans. Walk good.

March 29th, 1972.

Barry Floyd.

P.S. Don't miss reading The Caribbean Geographer, an annual newsletter sponsored by the G e ography Department U.W.I., featuring reports from many universities, professional organizations, and individual scholars $w$ it h teaching and research interests in the Caribbean. It will help you to put your finger on the pulse of the subject, both within and beyond the West Indies. Volume 2 of the Caribbean Geographer will be published in May, 1972.

See also D. Cowenthal "Black Power in the Caribbean Context" in Economic Geo-
graphy Vol. 210 No. 1 (Jan. 1872). Pp. 116134. 


\section{On The Academic Goals and Research Objectives of the Emerging School of Indigenous Caribbean Geographers}

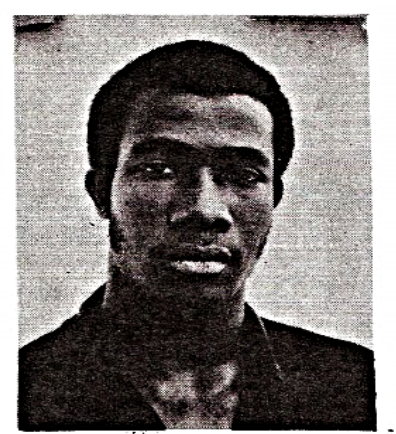

The growth of knowledge in the past centuries has necessitated the "division of labour" among scholars which has seen the birth and maturation of numerous disciplines. Each one has been faced time and again with the task of defining its perimeter and its internal objective but some have found it easier to do this than others. The very nature of geography, as the study and synthesis of phenomenal interrelationships, has made its definition and aim more difficult than many other discilpines, and to some, even impossible. For Caribbean geography this task of defining its scope and projecting its relevance is made harder by tenfold.

One distinguished geographer, R. E. Dickinson, remarked "Geography is what geographers do" and if we use this to examine the emerging school of indigenous Caribbean geographers it would become evident that there is need for a chartered course towards academic goals and research objectives. Most of the Caribbean geographers are engaged in teaching and this is likely to be so for a long time to come unless they create other openings for themselves by showing what a geograher is trained to do and is capable of.

The first aspiration of the indigenous Caribbean geographer is to charge the image of geography which now prevails in many

\section{by Keith Rowley*}

schools and other circles that it is a subject for junior school but is valueless in higher education. It is no secret that even though the primary concern of our present geographers is in teaching the discipline, the geography syllabus and teaching methods are among the worst in nearly all the schools. Too often we hear that to study geography is to memorise place names and sizes. This is the fault of many of our geography teachers and it would appear that this is the only thing they managed to do effectively. This destructive element must be weeded out immediately if there is to be hope for meaningful geography in the Caribbean. Geography degenerated to this level and found it impossible to elevate itself because nearly all the teachers are untrained in teaching methods and the University must introduce even a short course for prospective teachers, viz. undergraduates, in the presentation of geography at high school level so as to save the junior geographers from "capes and bays" geography.

The next academic goal should be to examine very carefully the subject matter to be presented. This must be foremost in the minds of all progressive Caribbean geographers since the main complaint echoed time and again is the unsuitable nature of much of what is taught. This could be attributed at lower levels to the public examination system coupled with a dearth of relevant textbooks. The need for readjustments from British geography to Caribbean geography is the greatest challenge for Caribbean geographers. The system has created an academic stalemate out of geography and this could be easily seen by comparing the expansion of geography with other sciences in secondary schools and other institutions. There is an acute need for us to do more writing and more importantly the setting of the exams to be offered from Cambridge or from our future Examinations Board. This will remove the yoke of inflexibility which now stifles many a well-meaning geography teacher. Meaningful geography must be bypassed in order to prepare students for foreign exams; this does little in the way of progress.

Restructuring of the entire curriculum is overdue. The junior geography course should set the world in perspective to the Caribbean and this is to be taught from specially prepared textbooks which should stimulate a sense of enquiry among young geographers. This would be the launching pad for the Senior School geography with the accent on establishing a sound general knowledge of the physical and social sciences which relate and interrelate to give the complex spatial patterns that are the subject-matter of the geographer. The homeland should always be emphasised to bring out wherever possible the features generated by physical and human interrelations. The curiosity developed in junior schools is followed by the search, observations and explanation of the Senior School.

At the undergraduate level a broader and more complex treatment of spatial variations and physico-human relationships is to be encouraged in the fashioning of a career goal.

Having sought and achieved reorganisation of the academic outlook the Caribbean geographer will now be well on the way to "doing" geography. As in many other situations developing countries are spared the effort of trial and error since they have a variety of already established ideas in other underdeveloped, developed and overdeveloped countries from 
which to choose. The Caribbean geographer is working in a region where there is a lot to be done and also one where relevance is stressed. We could ill-afford the hyperacademic inclinations of some schools but instead we need a discipline based towards the applied side and we could not have been more blessed with a better school to emulate than the Soviet school of geography. True it is, that these two areas are vastly different in scale of operation but the approach of the discipline in the Soviet Union - with an emphasis on the practical application of geography, is what we need to copy. If any region in the world could be used to show that geography has a role to play, the Caribbean is that region. Like the Soviet Union our emergence is relatively recent and our problems are similar in nature though not in magnitude and the admirable way in which geography is put to use in the U.S.S.R. has gone a long way in answering the questions as to whether geography is worth studying and if so how much could it contribute to development.

So far I have attempted to point out that what is most desired in the development of the discipline in the whole region is the restructuring of the various curricula towards a disciplining goal. This will give a fillip to the spirit and purpose of geography. Geographers sometimes use the concept of laissez-faire - if something is worth doing then someone will do it yet it is geography which in itself proves this to be otherwise. There is so much to be done yet nobody, or more accurately, hardly anyone, is doing anything. The reason for this is the lack of contact between geographers once they leave the University and migrate to their "airtight" islands. With this present state of affairs no Caribbean School of Geography could become a self-asserted reality. A handful of overworked lecturers and a roomful of students taking dictation is far from my idea of a school of geography. The plea for a medium of contact which en- sures that graduate and undergraduate geographers meet at least occasionally to air their different views, is synonymous with a plea for a school of Caribbean geography.

The role of the University should include the fusion of efforts of all practising geographers whetheir teachers or otherwise in an Association of Caribbean Geographers. The least it could do is organise a regional conference to further the aims of the discipline by stimulating the desire for radical changes and worthy efforts. Through this Association various regional papers could be produced by geographers who otherwise sink into oblivion disguised as teachers. The lack of incentive has been a major contributory factor in the degradation of Caribbean geography. From concise regional studies published through the Association suitable textbooks could be compiled. The shortage of indigenous literature is proof of the barrenness of Caribbean geography.

Once the stage is set for the exchange of ideas and for intellectual discussions the next automatic step will be the presentation of research papers through the machinery of the Association. There is no shortage of problems to be tackled and it serves no purpose to try to list them here. However, it would follow that from these research papers would come valuable information which could be useful to one or many of the fledgling planning units which exist throughout the region whether it be education, agriculture, fishing or industry. O Once the geographer has shown what he could do his acceptance, which is surely needed in other professional fields, is only a matter of time. I would like to stress here that there is no worthwhile future for geography in higher education unless it has a future in the materialistic outside world. This is the challenge to which the geographer must respond and the academic geographer then, must through his organisation and exe- cution of his discipline broaden the horizon and put geography in its correct relation to the wider society.

There is very little research being done in the Caribbean by graduates who operate within the region. With the exception of the staff at U.W.I. very few, if any, geographers contribute beyond the point of turning out students to an uncertain future. They are so content with their "teaching" jobs that they cease to respond to the very essence of their discipline, that is search, observation and ex planation. This deplorable attitude is reflected in the fact that the geographer who researched the U.O.C's Kingston project and produced a paper on it came from the U.K. (Clarke). He did this before any member of the J.G.S. social club. What these geographers do not realise is that if geography in the Caribbean means the vicious "teaching" cycle then whatever virility it now has will be shortlived because as soon as the schools become adequately staffed (in number) the surest way to unemployment would be to acquire a geography degree. If one looks at the number of graduates expected over next five years or so this funeral is not too far away. The incentive to read geography will be destroyed by the failure to create openings for geographers and to a certain extent we will have ourselves to blame. This could only be averted if we could show that there is more to geography. We must find ourselves engaged in planning and development in the categories. (How many geographers work in land authorities, family planning, industrial location, etc.?). These sectors will only recognise geographers when they have proved their worth and this is dependent on the efforts and achievements of organised research on the part of the present graduates throughout the Caribbean Their work should serve as show. pieces i.e. advertisement of latent potential:

(Continued on Page 27)

Page Fourteen

THE FLEDGLING 
producing the sugar, cocoa, bananas and palm oil, continues to produce these crops, paying no attention to the changing composition in the demand in the foreign sector. This is due to the specific nature of their capital equipment, which hinders a change over to other crops, and the fact that since many of the companies owning the plantations, are integrated vertically they can recoup losses on the sale of primary products at higher stages of production.

The dichotomous economics of the third world with a "modern" and "domestic" sector, are to be seen throughout the Caribbean and the rest of the third world. The dichotomy is not only evident economically but spatially as well. This spatial anomaly camnot be analysed solely in terms of "locational factors" but other factors must be taken into consideration as well. Furthermore there seems to be a strong case for analysing the two sectors separately, taking a careful look at the integration of the modern sector into the economies of the metropoles, since there are more links between the two than there is between the domestic sector and the foreign sector, though both are geographically within the same country. This question could pose a definitional dilemma for economic geographers, since there is a divergence between the spatial location and economic orientation of the two sectors, though they both exist within the boundaries of the same national economy.

\section{LANDSLIDES}

(Continued from Page 19)

fault will be shaken greaty. Another reason affecting the sliding is that this hill is very steep and shear, so it is unstable. The centre of gravity is in the middle of the Mountain; that means that any surface higher up the hill will be unstable and will have a very high energy potential. If any provocation such as a shock is added to the area the hill will slide.

In the area north-west of Highgate the slide is low angled and is c a u sed by the underlying mud stone i.e. the Langley mudstone. This mudstone contains clay silicates which absorb vast amounts of water thus becoming very soapy and acting as a lubricant for the above formations which just slide off the mudstone. The rain acts in two ways (i) It makes the mudstone slippery (ii) it increases the weight of the formation on top thus making them heavier and much easier to slide off.

- Mary is a final year student reading Geography and Geology.

\section{ACADEMIC GOALS OF CARIBBEAN GEOGRAPHERS}

(Continued from Page 14)

The emerging school of Caribbean Geography has a role to play but as it stands now it is in no position to make its presence felt as well as it might. In fact the very development of the discipline is threatened if the goals we set ourselves in theory do not show signs of realisation. The growth of the discipline is going to be a function of the achievements of the geographers and as long as this remains next to nil continued geographic expansion will leave much to be desired.

I conclude by maintaining that the major goal of the Caribbean geographer who wishes to participate in a rejuvenation of Caribbean Geography is to make a bid for relevance in an effort to prove the worth of geography academically and especially from an applied standpoint.
- Michlography Michael is a Final Year student reading Geography and Economics.

1. J. S. Mill, Principles of Political Econ-

. Raoul Probisch, Towards a Dynamic Development Policy for Latin. U.N., ECL.A. developed Regime. L. Best, "A Model of Pur

5. L. Best, Op. cit.

G. L. Beckford, Persistent Poverty. V. C. Mulchansingh, "Energy and the Third World".

V. C. Muichansingh, "The Multinational Oii Corporation"

H. Myint, "The Gains from International T. A. Theberge (ed) Economics of Trade and Development.

H. W. Singer, "The Distribution of Gains between Investing and Borrowing Coun tries" in Reading in International Ecomics. $R$. E. Leves and (ed).

D. Seers, "The Mechanism of an Open Petroleum Economy". S.E.S.

Inflation and Growth in Underdeveloped Economics based on the Experience of Latin Amer. ica O-E.P. 1962.

W. Girvan and o. Jefferson, "Corporate versus Caribbean Integration" in New
World Quarterly, Vo. IV. No. 2.

\section{PATTERNS OF RELIGION IN JAMAICA}

(Continued from Page 24)

tradition may through the men now going through UTC, begin to grasp once more the prophetic function which it has long since abandoned, even that which it had.

PLEASE

SUPPORT

OUR

ADVERTISERS 


\section{A SHORT NOTE ON CLIMATOLOGY IN THE SCHOOLS OR IS WHA GO ORN?}

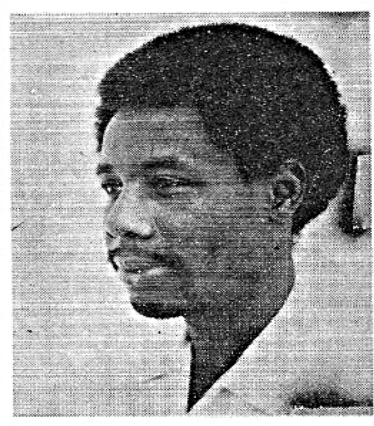

Elsewhere in this issue (see $\mathbf{K}$. Rowley, "On the academic goals . . . Caribbean Geography") the reader is introduced to some of the ideas that should engage the attention of an emerging school of Caribbean geographers. This short note is not an attempt to summarise Rowley's arguments, but merely to go off on a slight tangent and look at the problem through the eyes of the Geography graduate who is faced with teaching something of climatology to secondary school students.

In most schools of the Caribbean Geography teachers are manfully perpetuating climatological fallacies that should have gone out with the can-can. (For readers who are unfamiliar with the expression, they could check a favourite old aunt). There is the fallacy that the Caribbean lies in the path of rain bearing winds per se (This will be explained later); there is the fallacy that prevailing winds throughout the Caribbean are from the north-east. It would seem that no wind worth its salt would blow from any other direction. Textbooks are still used that describe all islands as having convectional afternoon showers each day and double maxima rainfall with the further assumption that throughout the area this has one cause. Not surprisingly, this kind of book tends to speak of the "tropical islanders" and one waits fearfully for the proverbially huge

\section{by Vincent George*}

mosquitoes to come charging out of the bushes.

There are fallacies by omissionthe omission from many syllabuses of easterly waves. It seems here, however, that the Met. Office at Palisadoes and the Department of Georgraphy have conflicting ideas. The former says that the easterly waves disappear over Haiti; the latter teaches that they reach as far as Jamaica. To continue though, there is the omission of the effect of "northers" and cold fronts over the northern Caribbean especially, and, perhaps the most surprising omission of all - the omission of the kind of contribution of hurricanes to Caribbean precipitation. What is known is that hurricanes have women's names, tend to blow down coconut trees and contribute a "bad thing". In addition, what is presented is static climatology. The student leaves with the feeling that the higher latitudes have nothing to do with the Caribbean. What is needed is not an exposition on the Hadley cell and the jet stream but first the theory of energy flows simplified. Theories that explain simply the transfer of energy from low to high latitudes are not introduced. The secondary school child is taught in effect that the Caribbean has a very simple precipitation regime in a very simple tropical climate with no real differences between Cuba, say and Guyana. "All ah we is one", that Trinidadian phrase, seems to be the unconscious climatological motto among most teachers.

The student is taught that as the islands intercept the "rain-bearing winds" these winds are forced to rise and then "the moisture condenses and falls as rain." There is no point in Barbados over 1,200 feet. And yet no section of Barbados receives less than 40 inches of precipitation. With the average temperatures and humidities pre- vailing over Barbados, the island would need a range of about 3,000 to 5,000 feet to cause a rise high enough for the relative humidity to reach $100 \%$ and a precipitation similar to the one that exists at present.

The fact of the matter is that most of the precipitation in the Caribbean is caused by one of four agents - easterly waves, hurricanes, northers and disturbances in the I.T.C.Z. There is admittedly a small contribution by convection and topography but this is not really significant for the area as a whole. The major agent is the easterly wave. Put another way, the majority of Caribbean precipitation is "disturbance-line" precipitation. And these are disturbances superimposed on or temporarily replacing what is essentially a dryweather regime. Kingston for example, has on the average 79 rain days a year. For if the prevailing are winds caused by the subsiding of air around the sub-tropical high, then by definition they are dry winds. Precipitation could only be caused if the lid caused by subsidence is lifted. As argued above, Caribbean mountains, while they could accentuate the process in themselves cannot do this and this is precisely what graduate geographers teach in the schools.

Most Geography teachers disregard this and put forward convection and/or topography. But these cannot account for the peak in "summer" months, the drop for most of the southern Caribbean in the "winter" months and the winter peak for the more northerly areas. According to this theory, with wind direction and temperatures changing but slightly over the years, precipitation should likewise show correspondingly small changes. But most precipitation in the Caribbean is not really a function of temperature and topography. 
In respectable climatological circles the regular-like clockwork afternoon showers are as passé as the natives in grass shirts dancing barefooted on the white sand (or is it grey sand?). In the first place it is obvious that rain does not fall every afternoon. In the second place a commonsensical examination of the causes of these short afternoon showers will show that while the cause is temperature, it is too simplistic to describe them as convectional as the mechanics bear a marked resemblance to frontal precipitation.

Examination of wind roses something that the average child hardly hears of, and common sense again, would indicate that the prevailing wind direction especially of the southern Caribbean cannot be invariably north-easterly. And yet students take down diagrams with straight flow-lines for the Trades each at an angle of $45^{\circ}$ to the tropics (a Mercator's projection ) pointing to the "Torrid Zone" while a southerly wind may be coming into the classroom. Students hardly hear about surface deflection even.

The double-maxima of the northern Caribbean is easy to understand; the changes of wind direction in various parts of the area could be got across without too much trouble; Trinidad's "petit carene" should not be passed over as "something that happens sometimes" as it was taught to the author. The important differences between the northern and southern Caribbean could be outlined even badly. The widespread omission of the easterly wave from lessons on Caribbean climatology is difficult to understand.

One can only speculate as to what accounts for this situation. The historical complaint about the importation of ideas has some validity. The real thing is that the importation has ceased and for many, new ideas from outside stay outside. If they had continued to import they would be in a better position. It is a fact that for long temperate climatologists defined the I.T.C.Z. as a front which it is not. And yet this is the kind of information still current in the Caribbean about the Caribbean after it was expelled by temperate climatologists.

The author caunot subscribe to the exam excuse unless one is prepared to argue foolishly that examiners are unaware of the new findings in Tropical Climatology. And they are not. This leaves us with the argument that the students cannot take it or that the teachers clon't have it.

Students on leaving secondary s chool are reasonably wellacquainted with fronts, the causes and structure of mid-latitude depressions and westerlies. (They are also well aware of Wordsworth's seemingly perennial $\mathrm{d}$ a f f o d i l). The argument is that such a student would not be able to understand the theory of convergence and and divergence and the rela-

\section{With the}

Oompliments of

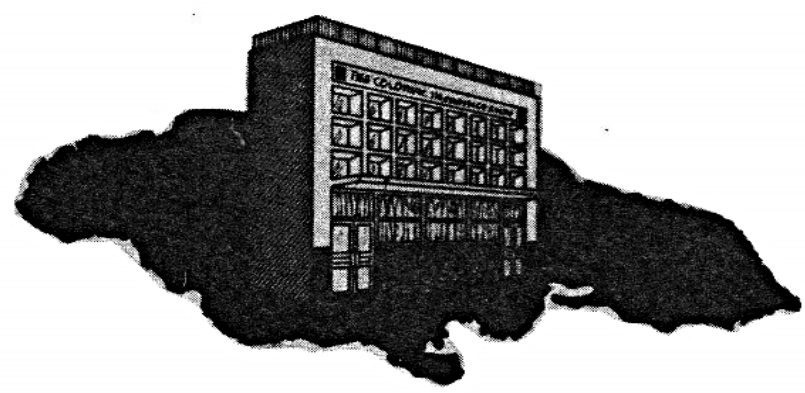

THE COLONIAL INSURANCE CO.OF JA. LTD.

62-64 DUKE STREET, KINGSTON TEL. 20240 
tion to precipitation. The natural science courses at A-level are reasonably exacting as are the liberal Arts courses. Students begin to chew on the light controversy in Physics and on Milton's grand style and symbolism in Conrad. And the argument is that such students cannot understand the theory of the Easterly Wave.

The other possibility was that the teachers might not know it. It would be sad if teachers trained in Geography should present this as an excuse. Geography is the discipline with search and research and keeping intouch at its very core - especially as so many of its concepts are being examined closely today.

One result of all this is that for the very exams that the students are being groomed, they are being groomed incorrectly. The author came upon an examiner's report in which the point was made that too often the student was wrong not because he did not have the facts but because the teacher gave wrong information.' Sparrow's point is well taken: The bright students tend to become "blockheaded mules". Another result is that the U.W.I. Geography freshman has to unlearn quite a bit of stuff. As an aside, one wonders how much of the consistently poor Geography results ${ }^{2}$ in the Englishspeaking Caribbean is due to incorrect tutoring.

This brief note is not meant to prepare a syllabus for the prospective teachers of Geography. Nor is it meant to be a summary of all the shortcomings in the schools' climatology courses. All it sets out to do was to suggest a direction for enquiry and to ask the question set out in the title: "Is wha go orn?" A further question remains to be answered: What are we going to do about it?

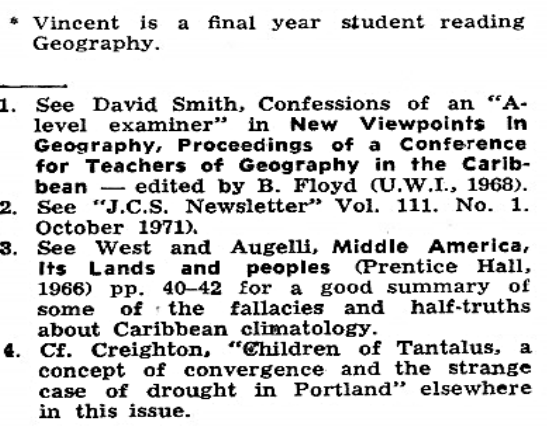
in this issue.

\section{LANDSLIDES by Mary Virtue*}

The study of landslides was carried out in three specific areas (i) North-west of Highgate (ii) Gorge between Landewey and (iii) Easington in the Yallahs Valley. These areas were chosen because they contain three distinctly different features of sliding as we will see further in the paper.

Throughout history landslides have occurred in great abundance in Jamaica. Unfortunately, however, only one of the great disasters was recorded with excellent examples and written up in the Philosophical Transactions of the Royal Society of London 1809 Vol. III, pp. 625-632. These are some of the accounts given on the landslides which occurred along with the 1692 earthquake - "Two great mountains at the entry into Sixteen Mile Walk fell and met, stopping the river so that it was dry from that place to the ferry"; arother in the same book was - "At Yellows a great mountain split and fell into the land and covered several settlements and destroyed 19 white people .. ." and yet another said "as to the mountains at Liguanea they fell in several places and in some very steep, but the steepest mountain that we had falling was at Gallowes:" The land slide at Yellows : r Judgement Cliff is still seen quite clearly with the fault scarp sheer and uncovered by vegetation, see Picture 1 . The people in the area all say that only one man in the village was saved, only because he was being unfaithful to his wife and sleeping in another area, while the whole village was covered alive.

Fortunately, however a serious slide has not taken place since about 1940 when a village in Portland is alleged to have been destroyed. However today we are affected by small but numerous land slides, which cause thousands of dollars to be spent each year on clearing the roads, etc.

Before we discuss the landslides actually studied let us look at (i) the factors affecting slides (ii) how slides take place.

The factors affecting slides can be classified into two groups the first being internal and the second external.

Exterral forces are the steepening or heightening of a slope by river erosion or excavation or by

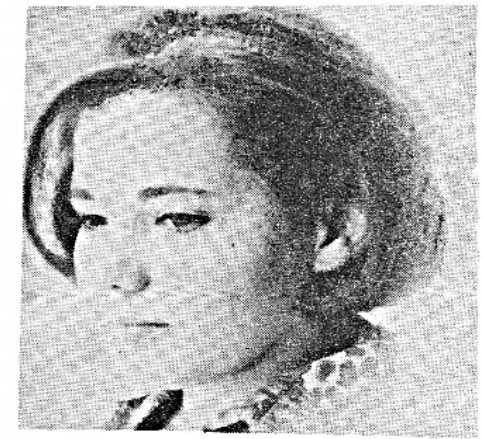

an external stimulus such as an earthquake shock.

Internal forces can be caused by the increase or pore water pressure, or by the progressive decrease of the cohesion of the material.

In the occurrence of a slide that is caused by external forces the reason for sliding will be very pronounced. However slides which were caused by internal forces are more difficult to be recognized and detailed studies will be needed to recognize it. All rocks have the property of shearing resistance; external and internal forces exhibit shearing stresses. If the shearing stress becomes greater than the resistance a slide will take place.

(Continued on Page 19) 


\section{Colin Hewitt's Photo Journal}

The following sample of contemporary photographs of the UWI, Mona Campus, trace its rich history. The photos of some of the signs and a few iconic man-made structures indicate that the campus was inextricably linked with Jamaica's history:

- "The Gibraltar Camp" Series, attest to the living conditions of the World War II detainees and further that, the camp functioned as a village.

- The "When Sugar was King" Series (Augier et al.), includes the iconic chapel, several photos of the remnants of the aqueduct, the Memorial to Jaghi, and finally, a plaque near the Chemistry labs, indicates the location of the village which once housed the enslaved Africans. 


\section{Photo Journal by Colin Hewitt (UWI, Alumni)}

\section{“Gibraltar Camp" Series}

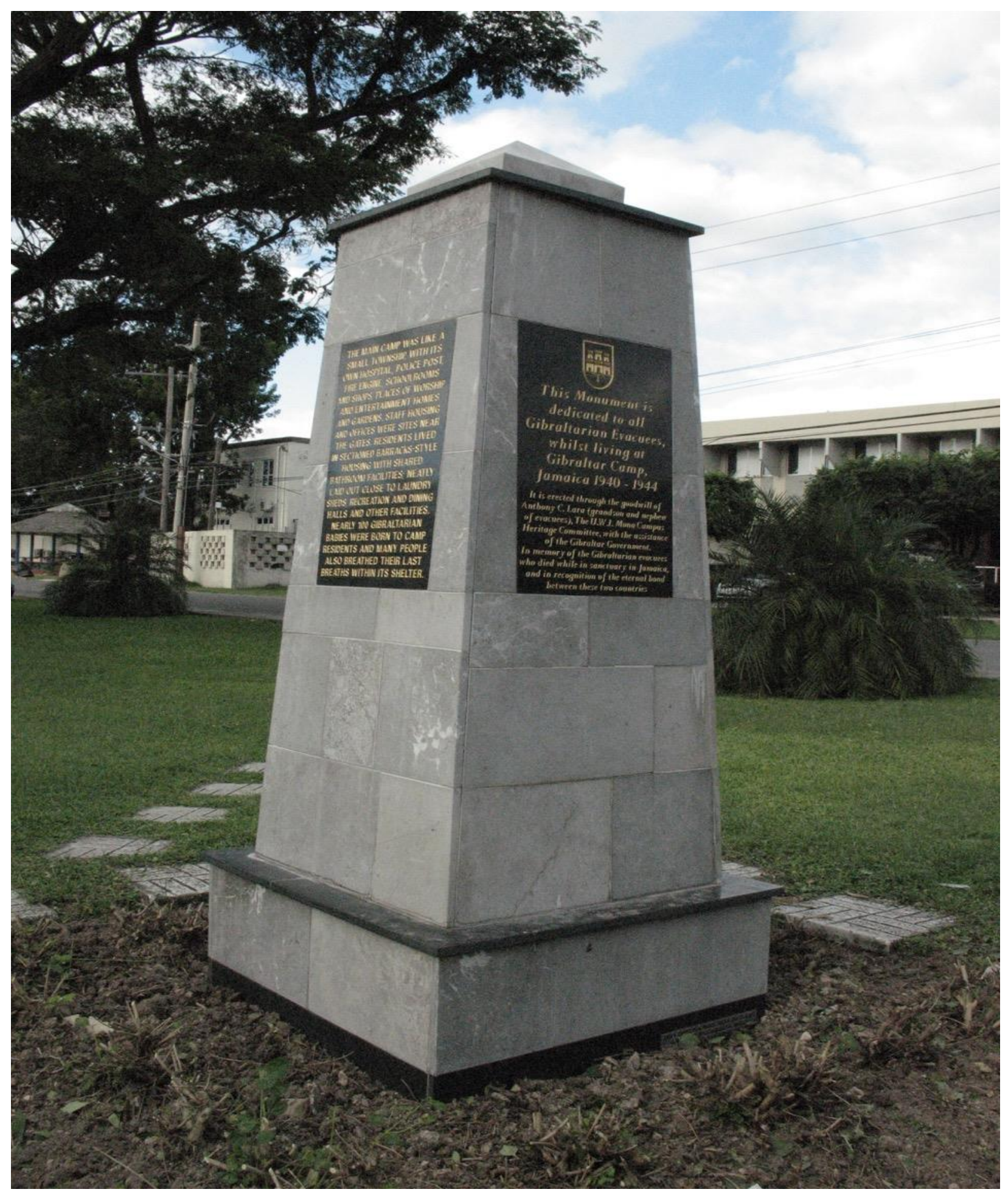

Cultural and Pedagogical Inquiry, Winter 2019, 11(1), pp. 21-60

ISSN 1916-3460 () 2019 University of Alberta

http://ejournals.library.ualberta.ca/index.php/cpi/index 


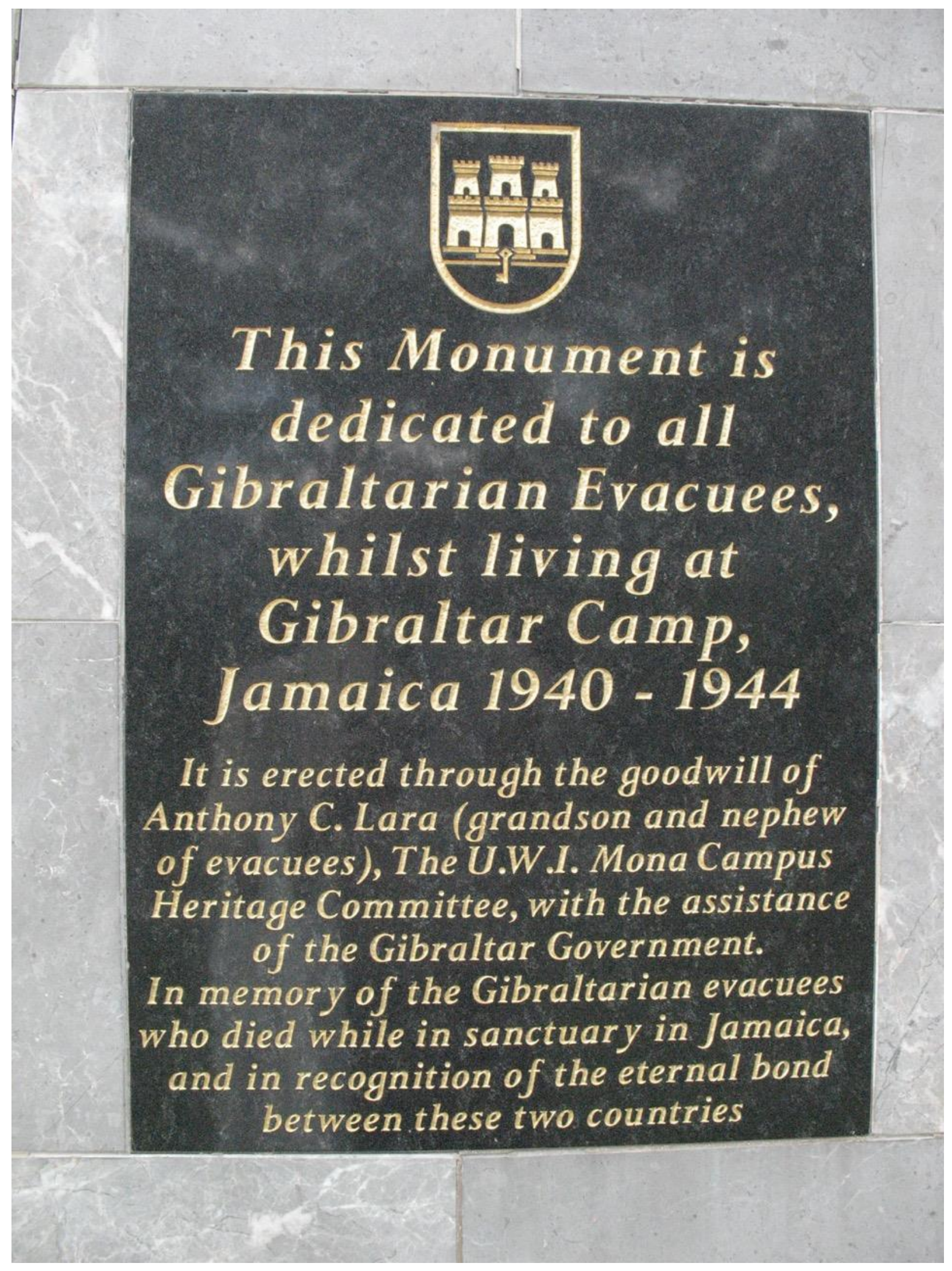

Cultural and Pedagogical Inquiry, Winter 2019, 11(1), pp. 21-60

ISSN 1916-3460 @ 2m019 University of Alberta

http://ejournals.library.ualberta.ca/index.php/cpi/index 


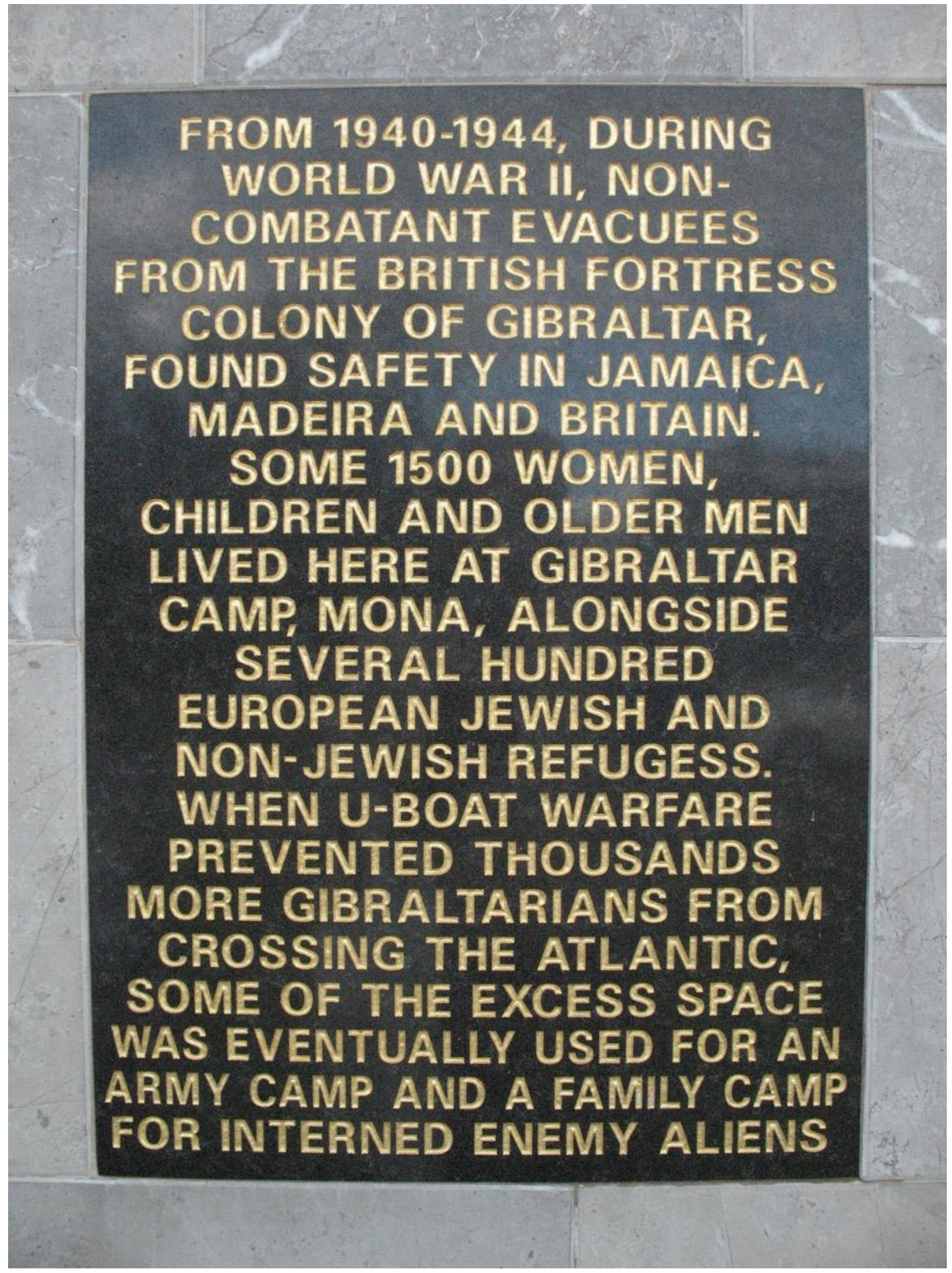

Cultural and Pedagogical Inquiry, Winter 2019, 11(1), pp. 21-60 


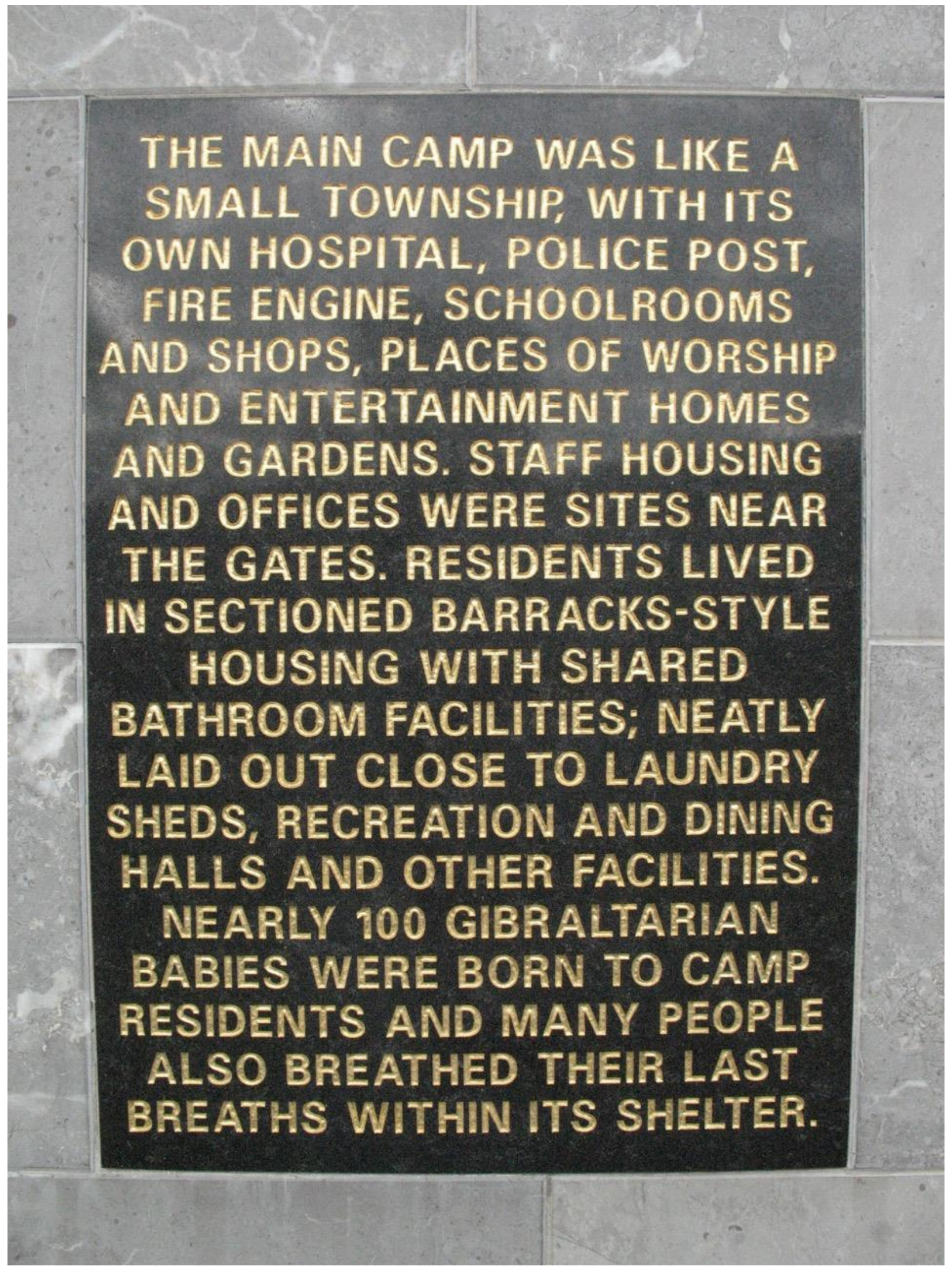

Cultural and Pedagogical Inquiry, Winter 2019, 11(1), pp. 21-60 


\begin{tabular}{|c|c|}
\hline \multicolumn{2}{|c|}{ SACRED TO THE MEMORY OF } \\
\hline ADAMBERRY, MANOLO & GOODMAN, ABDULIO \\
\hline AGIUS, SALVADOR & GARRO, LEOPOLDO \\
\hline ALVAREZ, OSCARIA & HASSAN, ABRAHAM \\
\hline ANDREWS, ROSE & HATCHWELL, MAZALTAB \\
\hline ARIAS, MARIA & HATCHWELL, MARIAM (Baby) \\
\hline AZZOPARDI, VICTORIA & HIPKINS, FRANCISCA \\
\hline BARDELL, JOHN & ICHE, HORTENCIA \\
\hline BASSADONE, CLEMENTINA & JIMENEZ, JOSEFA \\
\hline BAU, ANTONIO & LARA, ELIZABETH \\
\hline BELLIDO, HERMINIA & LARA, AMANDA \\
\hline BERTO, CATALINA & LARA, PETER \\
\hline BONITCH, FRANCIS & LIMA, MARY \\
\hline BORG, EMILIA & MARFE, ROQUE \\
\hline BROOKING, RICHARD Jr. & MARTINEZ, MARIA \\
\hline CARDONA, SALVADOR & MENAS, MARGARITA \\
\hline CARRARAS, JULIA & MORENO, EMILIA \\
\hline CARRIGHER, ANNA & MULLIS, HENRY \\
\hline CARUANA, JOSEPH & MUÑOZ, CRISTINA \\
\hline CASARETTO, VINCENT & PARDO, ERNESTO, \\
\hline CAVILLA, HERMINIA & PARODY, JOSEPH \\
\hline CELECIA, JOHN & POWER, EDUARDA \\
\hline CHICARDO, MANUELA & RAMOS, ANTONIA \\
\hline COSTA, ANTONIO & RISSO, MARIA \\
\hline CRUZ, JOSEPH & ROMAN, JOSE \\
\hline FALZUN, ANTONIO & ROWBOTTOM, WILLIAM \\
\hline FERRO, AMELIA & SANTOS, MARIA \\
\hline FIOL, ADELINA & SANTOS, (Baby) \\
\hline FLAHERTY, TIMOTHY & SMITH, KENNETH (Baby) \\
\hline FLOWER, CLEMENCIA \& Baby & TREACY BLANCA \\
\hline GARCIA, MANUEL & WOOD, ALBERT \\
\hline GOMEZ, JUAN & YEO, JOHN \\
\hline GOMEZ, CASTRO, AMALIA & AND OTHERS \\
\hline
\end{tabular}

Cultural and Pedagogical Inquiry, Winter 2019, 11(1), pp. 21-60 


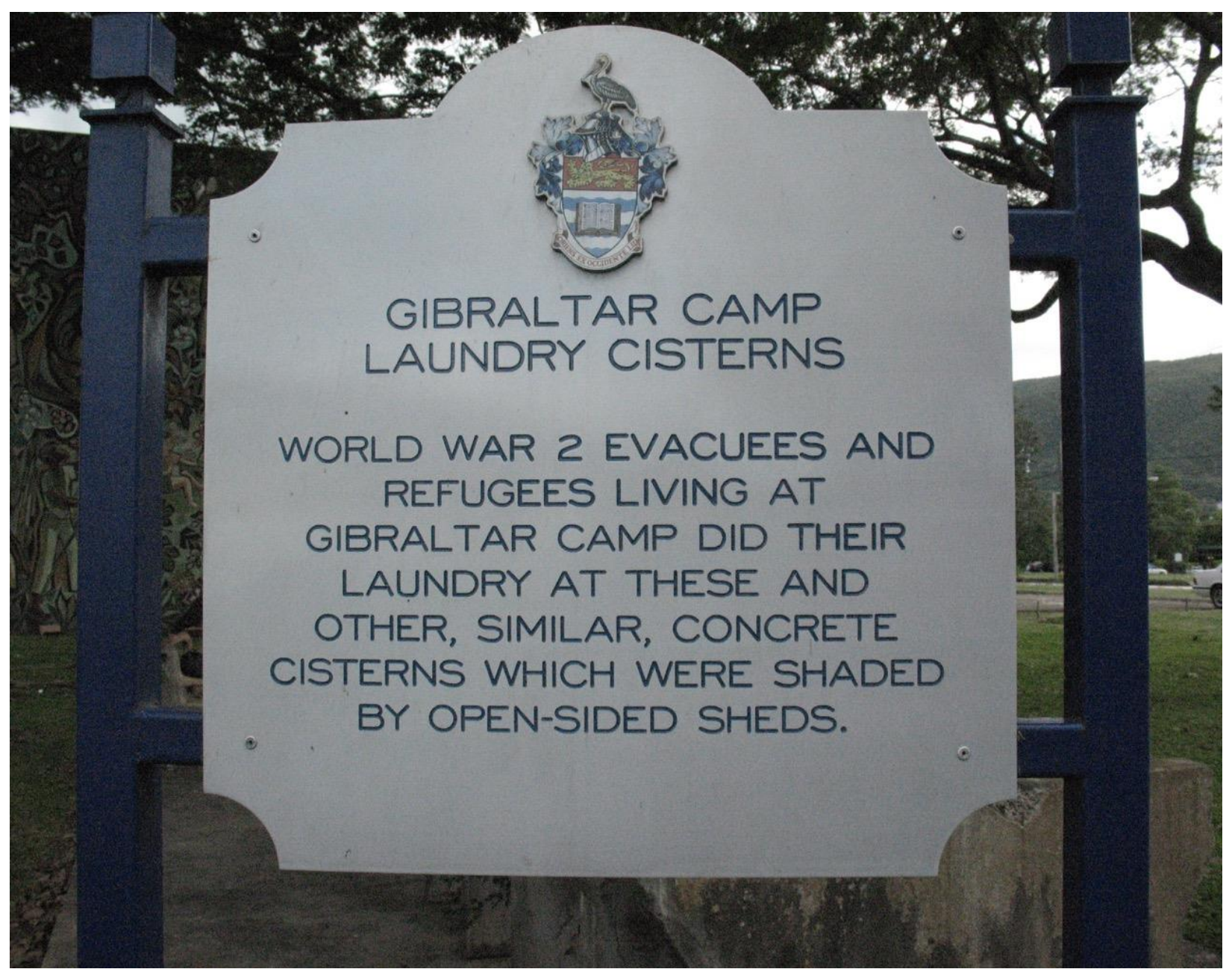

Cultural and Pedagogical Inquiry, Winter 2019, 11(1), pp. 21-60

ISSN 1916-3460 @ 2 m019 University of Alberta

http://ejournals.library.ualberta.ca/index.php/cpi/index 


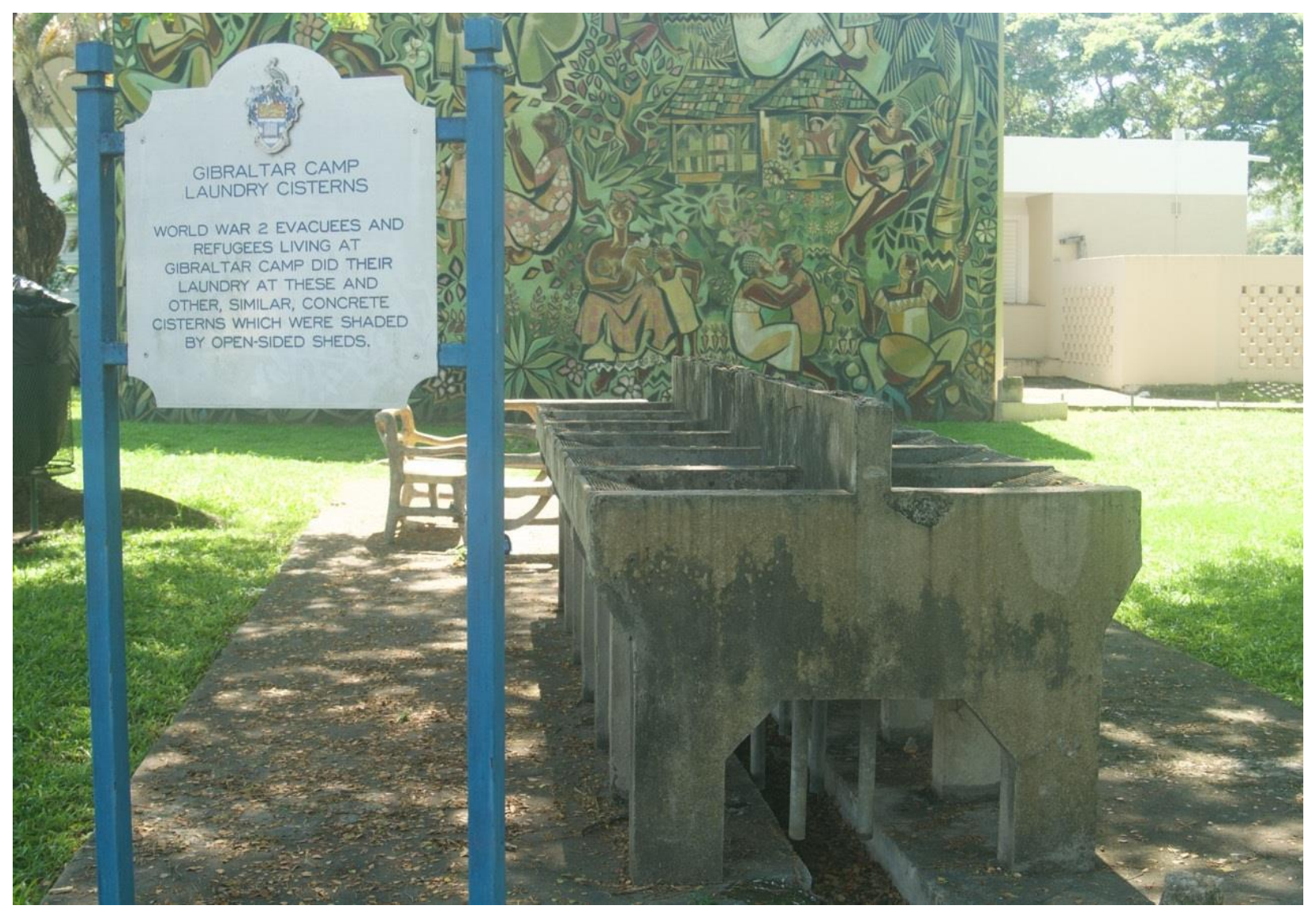

Cultural and Pedagogical Inquiry, Winter 2019, 11(1), pp. 21-60

ISSN 1916-3460 @ 2019 University of Alberta

http://ejournals.library.ualberta.ca/index.php/cpi/index 
"When Sugar was King" Series

(Augier, Gordon et al.)

\section{The UWI Chapel}

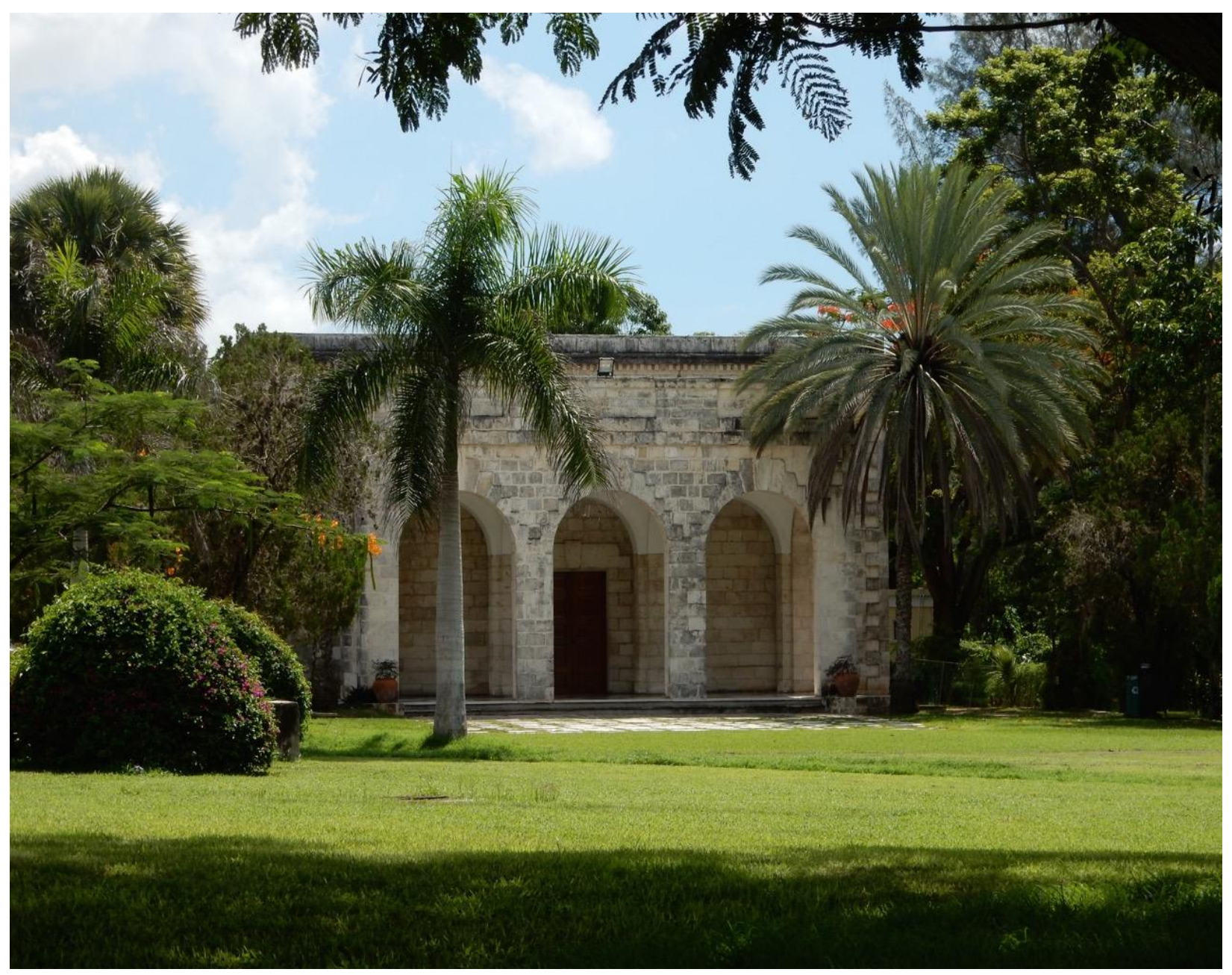

Cultural and Pedagogical Inquiry, Winter 2019, 11(1), pp. 21-60

ISSN 1916-3460 @ 2 m019 University of Alberta

http://ejournals.library.ualberta.ca/index.php/cpi/index 


\section{Aqueduct near Chapel}

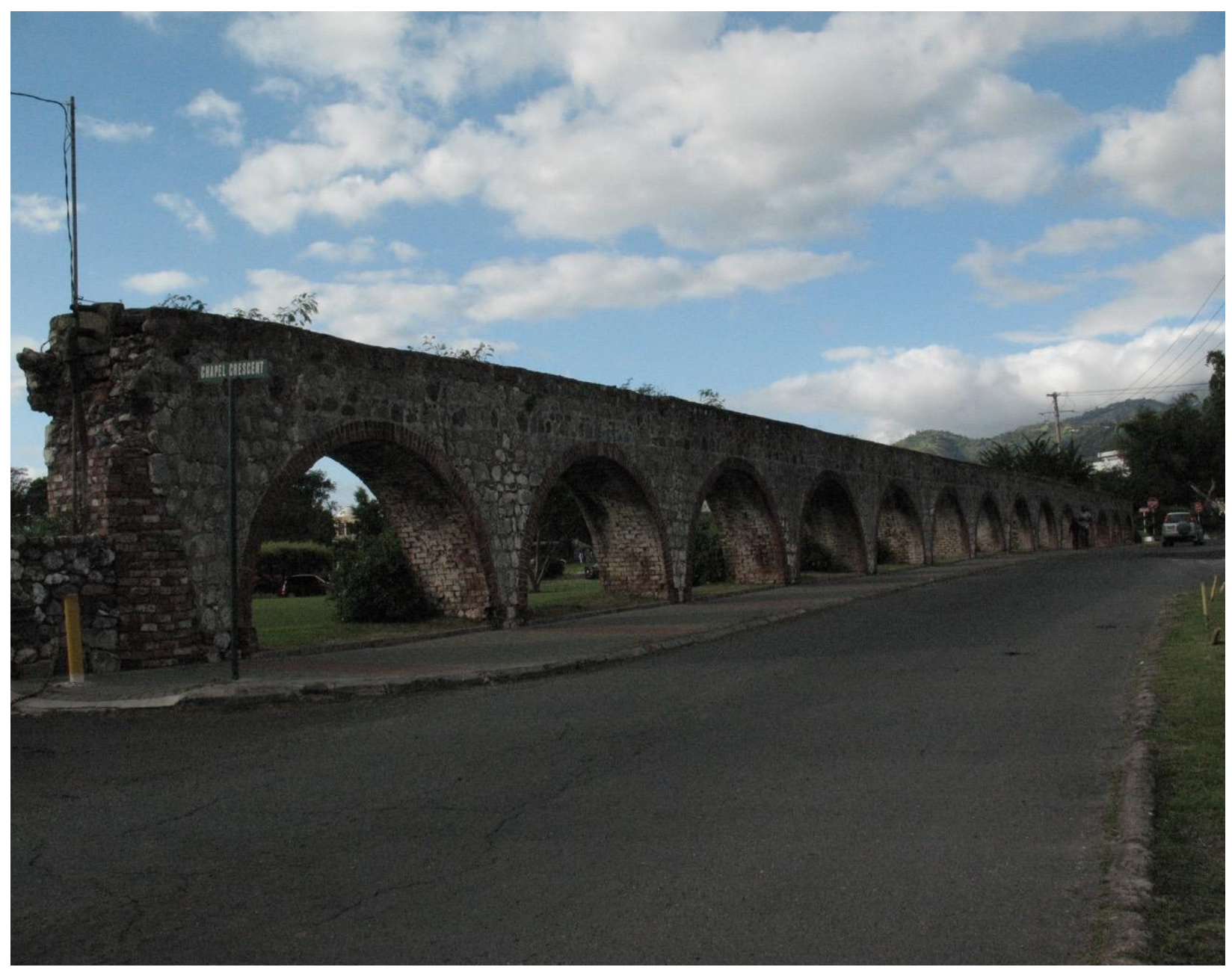

Cultural and Pedagogical Inquiry, Winter 2019, 11(1), pp. 21-60

ISSN 1916-3460 @ 2019 University of Alberta

http://ejournals.library.ualberta.ca/index.php/cpi/index 
Plaque: Near Jaghi's grave (Mona's links with indentureship)

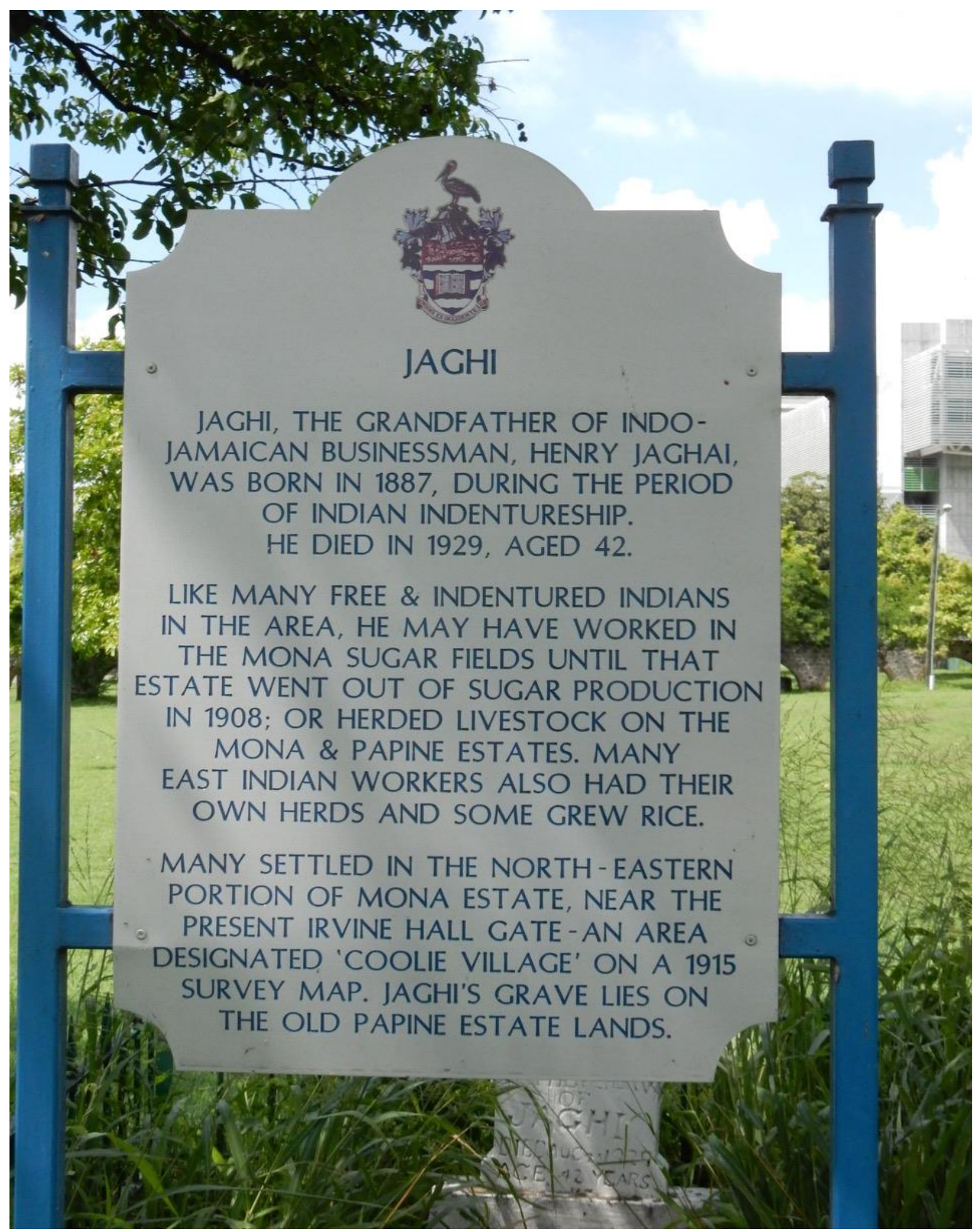

Cultural and Pedagogical Inquiry, Winter 2019, 11(1), pp. 21-60

ISSN 1916-3460 @ 2 m019 University of Alberta

http://ejournals.library.ualberta.ca/index.php/cpi/index 


\section{Plaque: Ruins of Papine Estate Sugar Works}

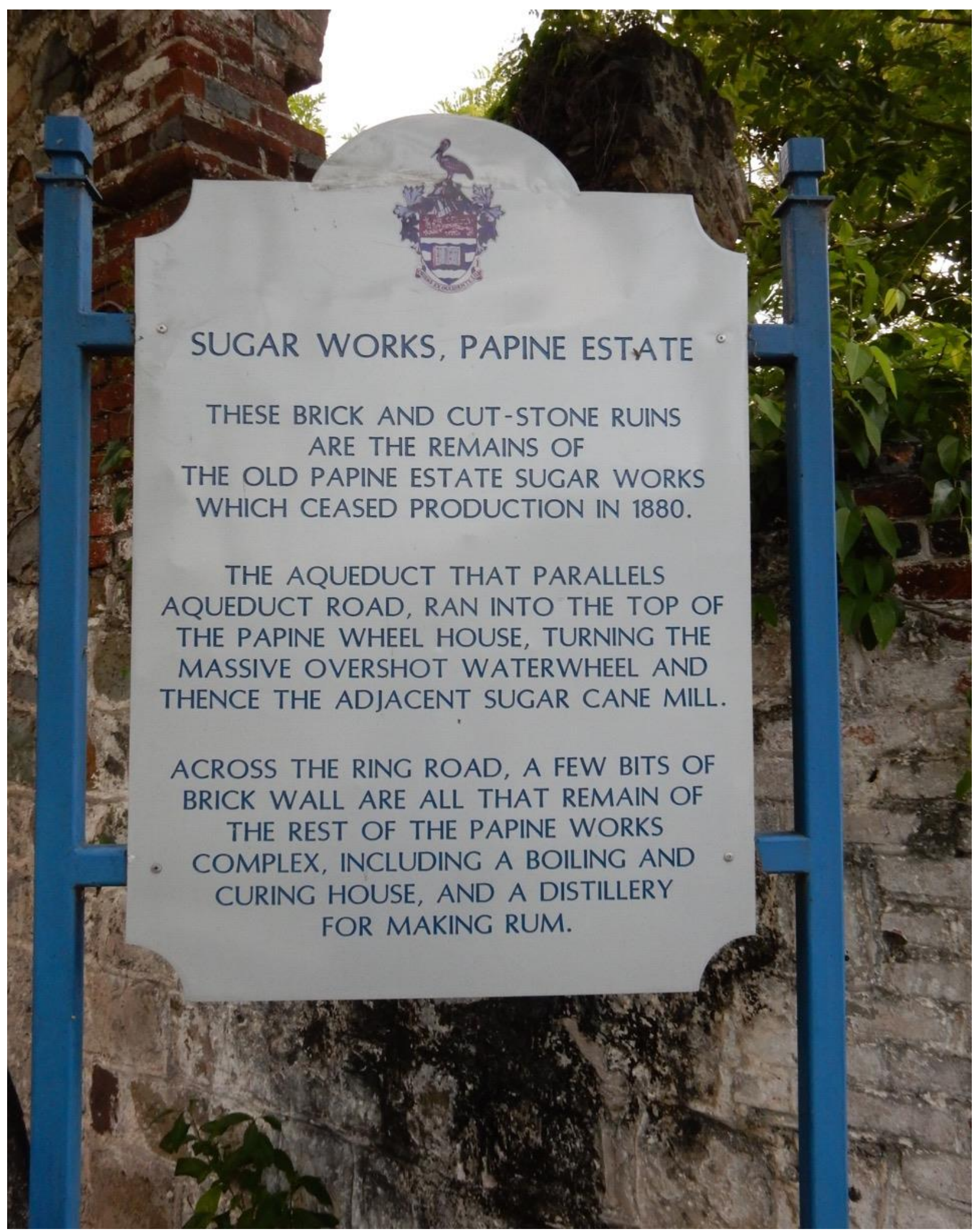

Cultural and Pedagogical Inquiry, Winter 2019, 11(1), pp. 21-60

ISSN 1916-3460 @ 2019 University of Alberta

http://ejournals.library.ualberta.ca/index.php/cpi/index 


\section{Aqueduct looking south towards old Sugar Works (West of Taylor Hall)}

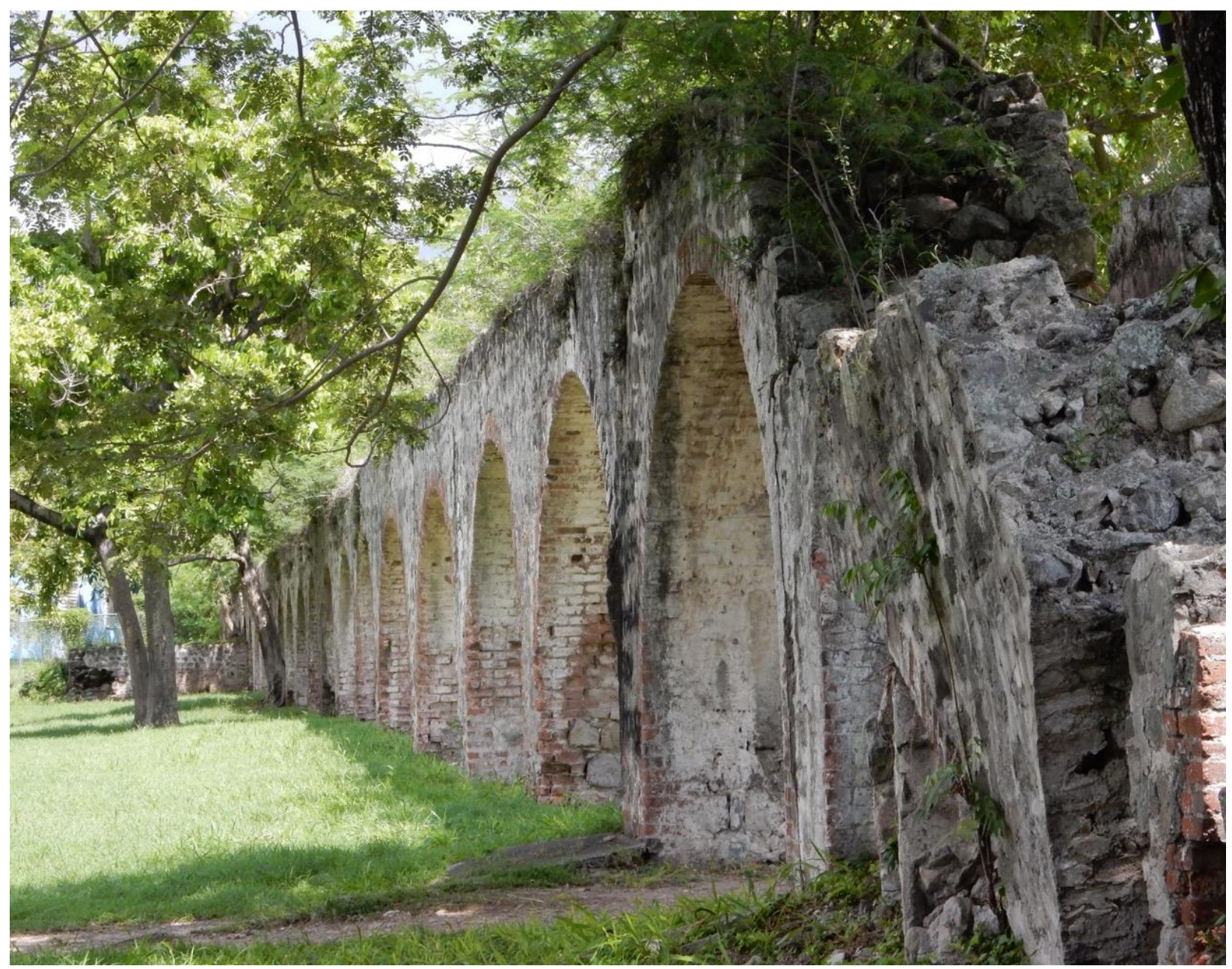

Cultural and Pedagogical Inquiry, Winter 2019, 11(1), pp. 21-60

ISSN 1916-3460 @ 2 m019 University of Alberta

http://ejournals.library.ualberta.ca/index.php/cpi/index 
Mona Village: Enslaved labourers, once worked on the estate, and lived in compounds in the vicinity (Monument outside Chemistry Labs)

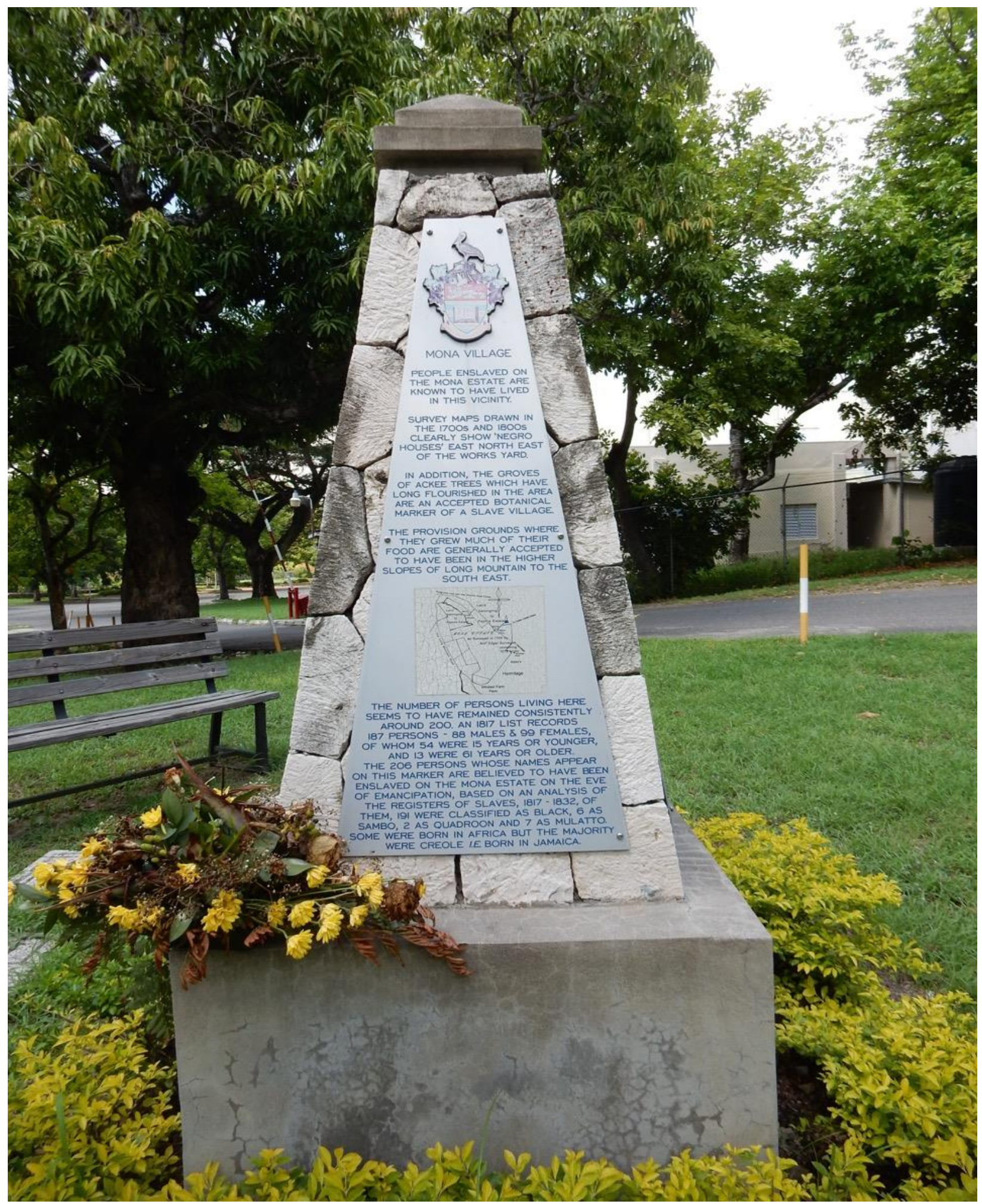

Cultural and Pedagogical Inquiry, Winter 2019, 11(1), pp. 21-60

ISSN 1916-3460 () 2019 University of Alberta

http://ejournals.library.ualberta.ca/index.php/cpi/index 
Mona Village (Monument outside Chemistry Labs)

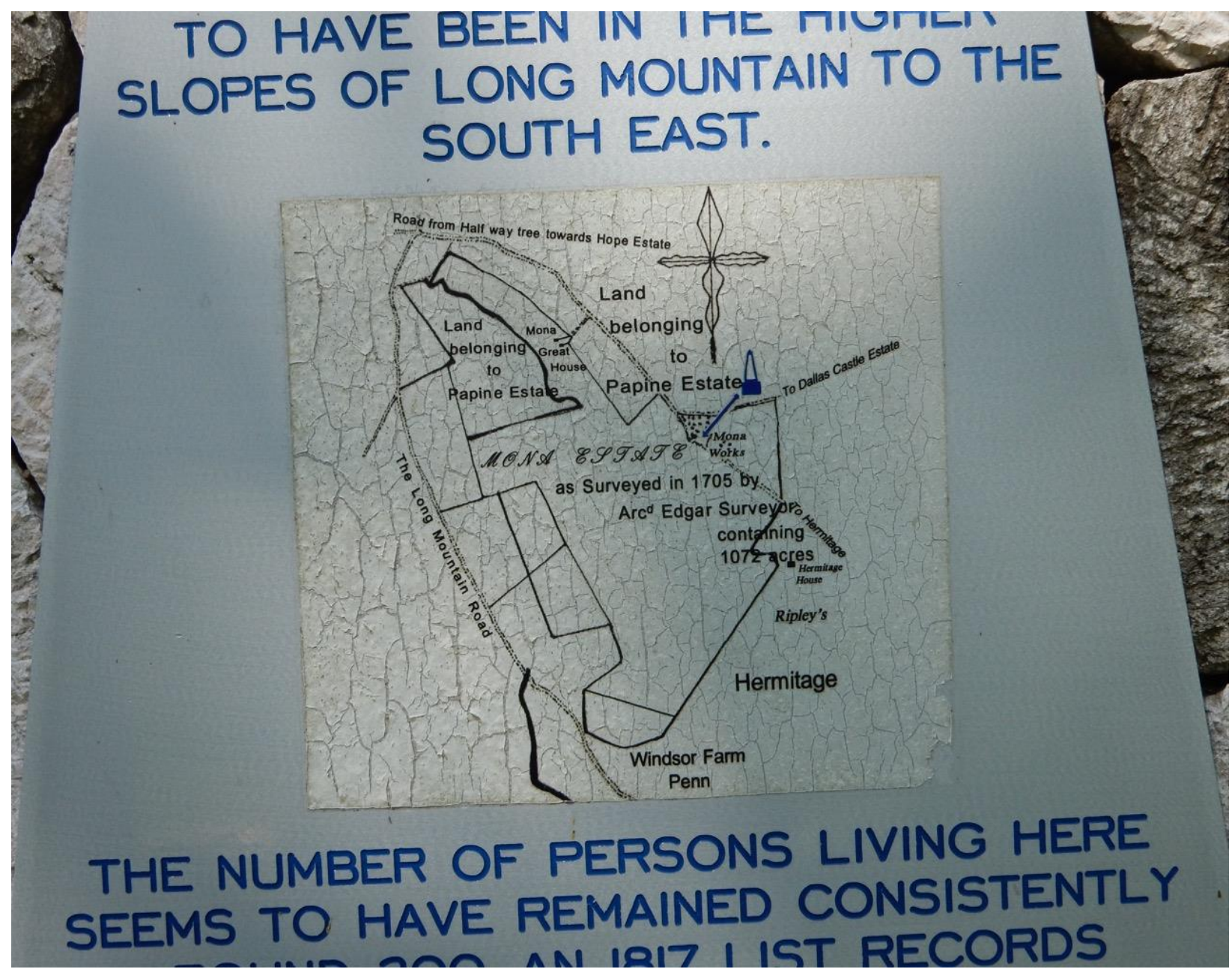

Cultural and Pedagogical Inquiry, Winter 2019, 11(1), pp. 21-60

ISSN 1916-3460 @ 2 m019 University of Alberta

http://ejournals.library.ualberta.ca/index.php/cpi/index 


\section{Mona Village (Monument outside Chemistry Labs)}

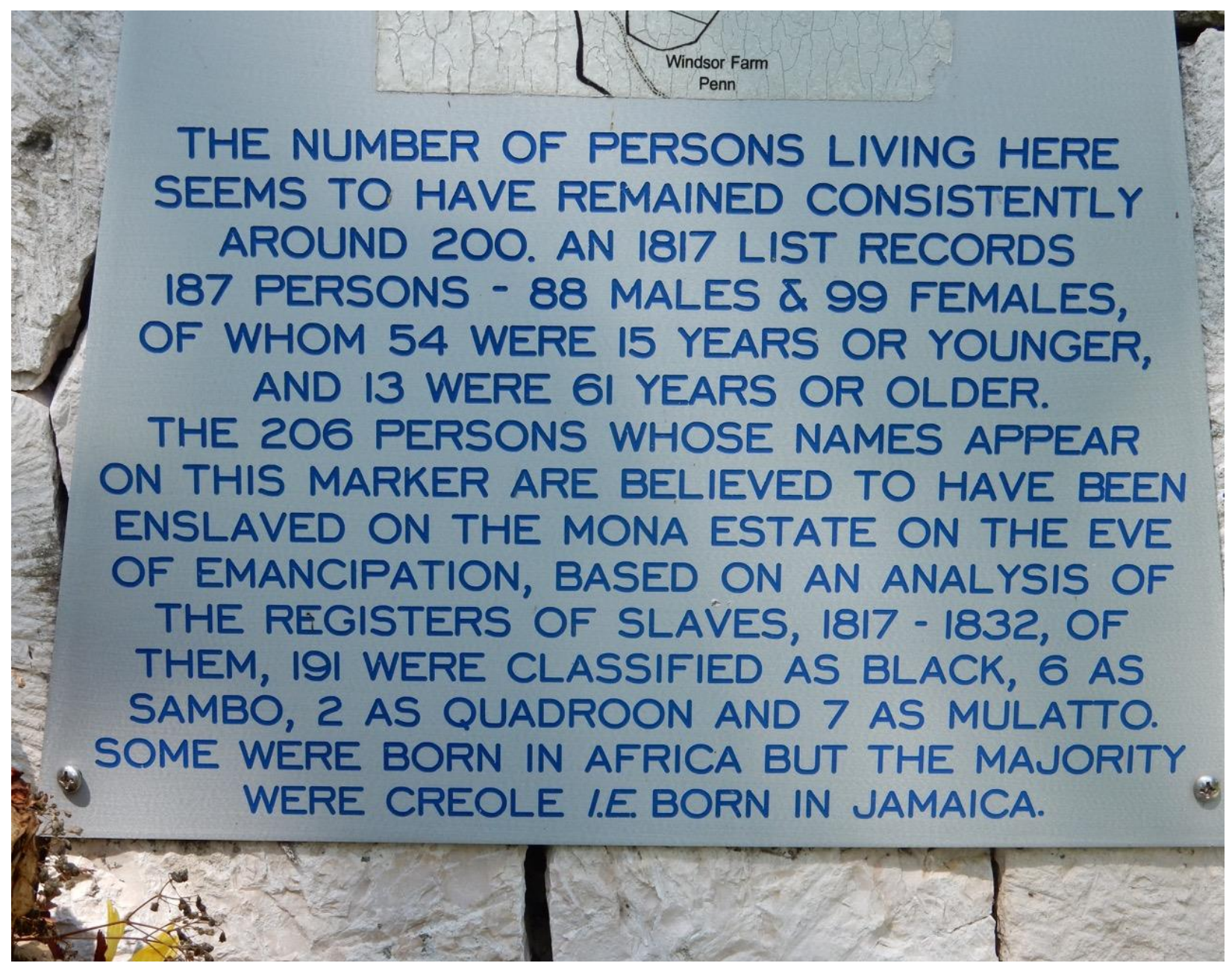

Cultural and Pedagogical Inquiry, Winter 2019, 11(1), pp. 21-60

ISSN 1916-3460 () 2019 University of Alberta

http://ejournals.library.ualberta.ca/index.php/cpi/index 


\section{Mona Village (Monument outside Chemistry Labs)}

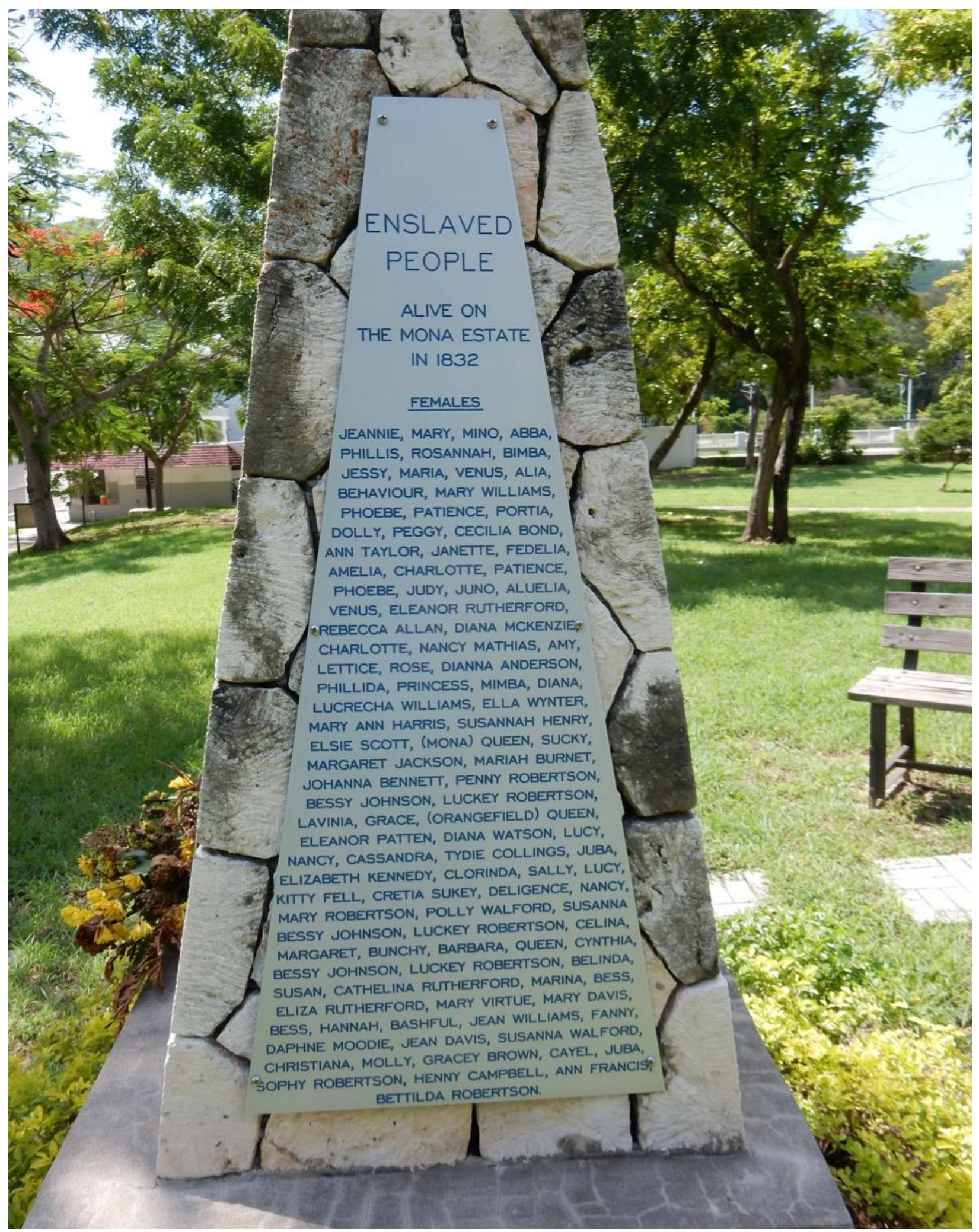

Cultural and Pedagogical Inquiry, Winter 2019, 11(1), pp. 21-60

ISSN 1916-3460 () 2 m019 University of Alberta

http://ejournals.library.ualberta.ca/index.php/cpi/index 